\title{
Net-Zero Carbon Microgrids
}

November 2021

Timothy R. McJunkin

Idaho National Laboratory

James T. Reilly

Reilly Associates

The Net-Zero Microgrid Program provides cross-cutting research to accelerate the use of renewable and zero-carbon generation in microgrids.

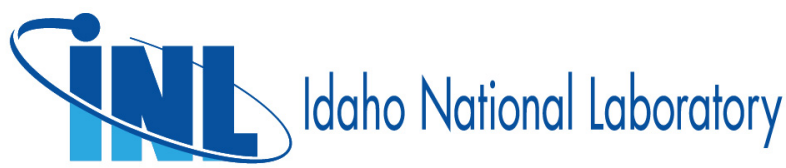




\section{DISCLAIMER}

This information was prepared as an account of work sponsored by an agency of the U.S. Government. Neither the U.S. Government nor any agency thereof, nor any of their employees, makes any warranty, expressed or implied, or assumes any legal liability or responsibility for the accuracy, completeness, or usefulness, of any information, apparatus, product, or process disclosed, or represents that its use would not infringe privately owned rights. References herein to any specific commercial product, process, or service by trade name, trademark, manufacturer, or otherwise, does not necessarily constitute or imply its endorsement, recommendation, or favoring by the U.S. Government or any agency thereof. The views and opinions of authors expressed herein do not necessarily state or reflect those of the U.S. Government or any agency thereof. 


\section{Net-Zero Carbon Microgrids}

Timothy R. McJunkin

Idaho National Laboratory

James T. Reilly

Reilly Associates

November 2021

Idaho National Laboratory

Idaho Falls, Idaho 83415

http://www.inl.gov

Prepared for the

U.S. Department of Energy

Office of Electricity

Under DOE Idaho Operations Office

Contract DE-AC07-05ID14517 
Page intentionally left blank 


\section{EXECUTIVE SUMMARY}

The microgrid concept has been effective in creating aggregations of distributed energy resources - generation, storage and loads - for resiliency, in the form of energy security. The success of microgrids in bringing energy security to a wide range of customers - from individual residences to commercial and industrial installations to military bases - has been exemplified during power disruptions and extended outages due to extreme weather events, cybersecurity attacks, and equipment failures.

Now microgrids have an opportunity to meet the challenges of climate change and contribute to a carbon-free power delivery system.

The transition to net-zero starts within microgrids themselves. In fact, today's microgrids are largely dominated by generators using fossil fuels, natural gas and diesel, with high greenhouse gas emissions. In short, the transition to netzero means replacing fossil fueled generators with renewable generation in microgrids. This transition is extended by including new dispatchable generation technologies that are $100 \%$ carbon-free and that offer additional advantage of a more-dependable and sustainable source of energy and power. Basically, the decarbonization of microgrids requires three elements: 1) maximizing generation from renewable energy resources, 2) management of storage and flexible loads to balance the variability and intermittency of renewable energy resources, and 3 ) introducing new clean power sources, including hydrogen-based generation and small modular reactors.

This report affirms a need for specific focus by governmental agencies at national, regional, and local levels to establish technology, policy, and investment in this area. The intention of the Net-Zero Microgrid (NZM) Program is to inform these constituencies with cross-cutting research and tools for the reduction of GHG in microgrids - to net-zero in the near term eventually to zero in the longer term. .

The NZM Program is committed to achieving decarbonization for resiliency and for providing clean energy at the local or distribution level, from remote communities to underserved communities, and large industrial and military facilities. The NZM Planning and Design Platform is a core tool to be developed as an early deliverable of the NZM Program because only a fully integrated microgrid-design approach will ensure maximum carbon reduction in energy production. 
This report begins by giving the motivation for implementing NZMs based on the accelerated push toward green power generation, the move away from reliance on fossil fuels, and the drive toward delivering clean power to consumers and greening distribution systems. The NZM can be a major step toward greening the electricity sector. If a large number of such microgrids are deployed, power distribution can be made increasingly green in the foreseeable future.

While the driver for microgrids for resiliency is noted, the report also notes that the trend toward distributed renewable-generation integration into distribution networks is an important incentive and driver for microgrids to be zero-carbon.

The economic considerations for the NZM business case are discussed in terms of relative fuel costs, configurations, and incentives necessary for parity with fossil-fuel-based generation. The volatility of natural gas prices and recently rising prices are noted as being favorable to the deployment of renewable generation. The value of the NZM with sustainable renewable generation given the risk of disruption in the supply of natural gas and diesel is explained.

Research and development projects are identified for consideration, such as advanced planning tools that can handle more-complex owner structures, gridtopologies, power flows, local energy markets, different tariff systems and dynamic pricing, and smaller time-steps to capture the volatility of renewables and enhanced controller functionality for managing microgrids with maximum renewable generation and minimal GHG emissions.

A bibliography of documents from an extensive literature search on topics related to net-zero carbon and microgrids is provided.

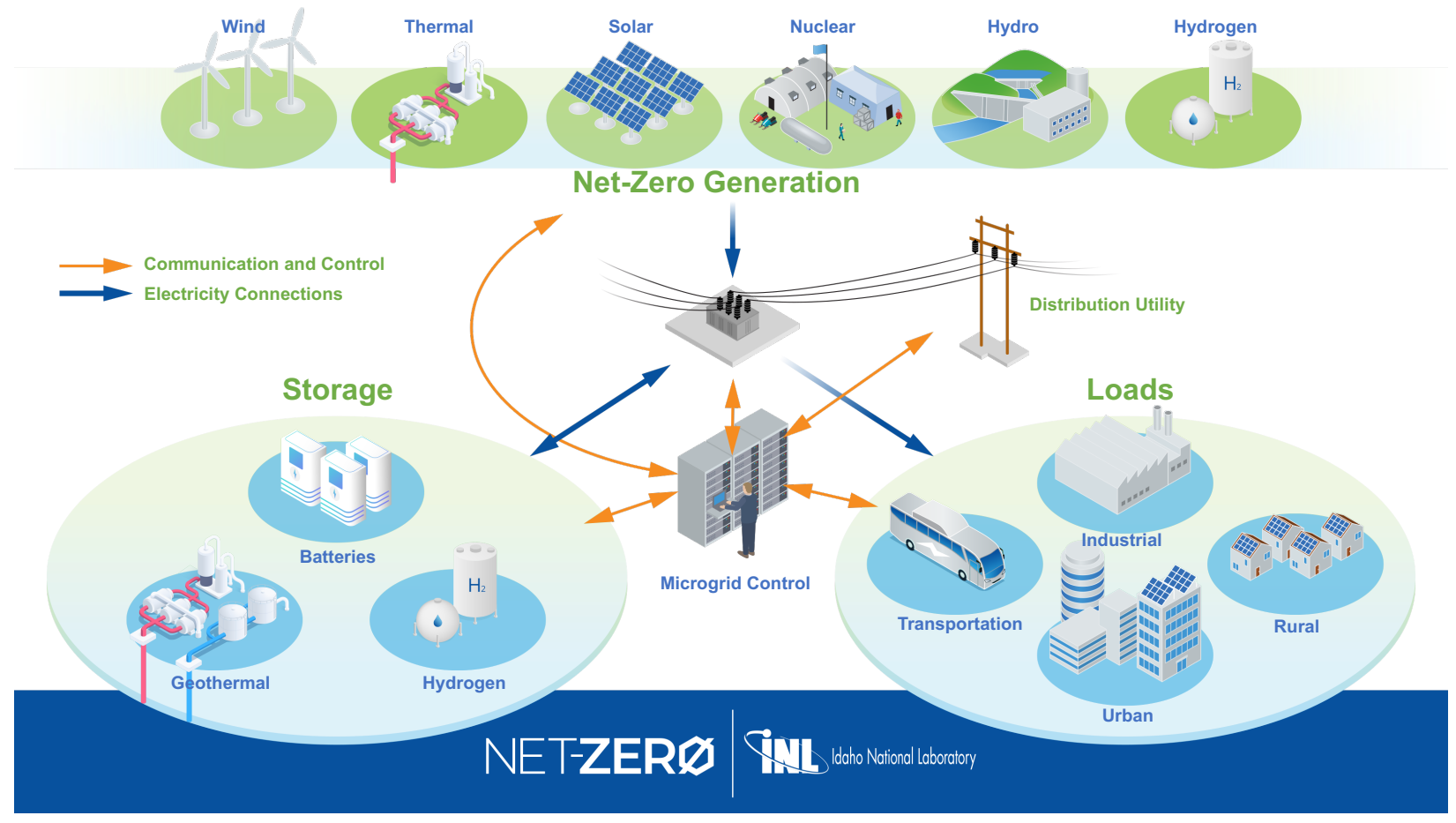




\section{ACKNOWLEDGEMENTS}

We thank Dan Ton, Program Manager, Microgrid Program, DOE Office of Electricity for his encouragement to pursue net-zero carbon solutions for microgrids and his support for the production of this report.

We are grateful for the market research, data and insights provided by Isaac Maze-Rothstein, Wood Mackenzie. The authors appreciate Michael Stadler for

discussions on the economic considerations for Net-zero Microgrids and the microgrid example cases comparing traditional microgrids and Net-zero configurations. 
Page intentionally left blank 


\section{CONTENTS}

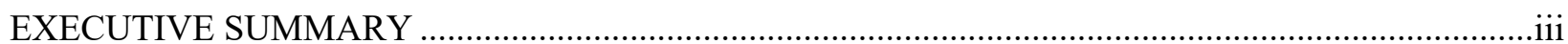

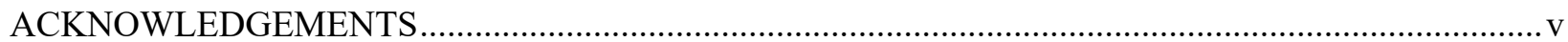

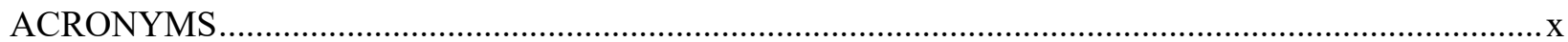

1. NET-ZERO CARBON MICROGRIDS - CONCEPT, STRUCTURE, AND

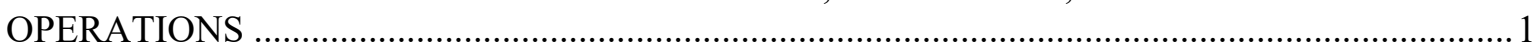

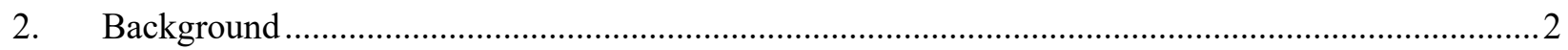

2.1 Role of the Net-Zero-Carbon Microgrid in Meeting Greenhouse Targets .............................2

2.2 Microgrid Design Considerations -Extension to Net-zero-carbon Grids................................ 3

2.3 Description of the Operating Modes of a Net-zero-carbon Microgrid ..................................... 3

2.4 Operating Modes of the Microgrid - Constraints Associated with a Net-Zero-Carbon

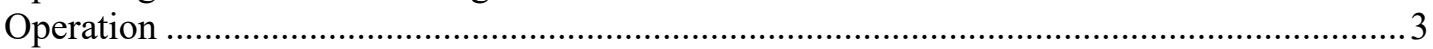

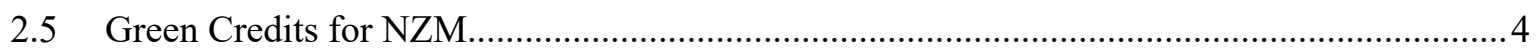

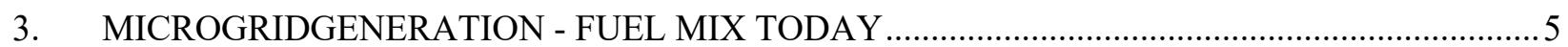

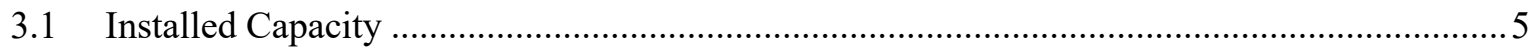

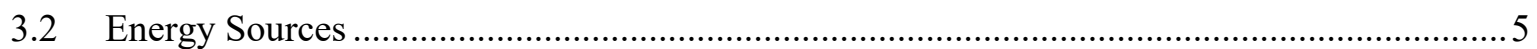

3.3 New Generation—Microgrids vs Macrogrid ................................................................... 6

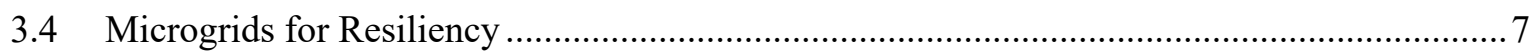

3.4.1 Pacific Gas and Electric Resiliency Plans .......................................................... 7

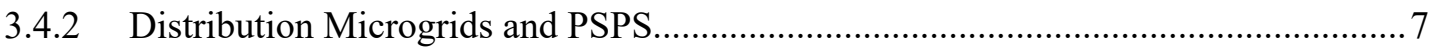

4. THE INTEGRATION OF RENEWABLE ENERGY IN MICROGRIDS ..................................... 9

4.1 Trend Towards Distributed Generation ........................................................................... 9

4.2 Natural Gas_-Price Volatility and Security of Supply ........................................................ 10

5. ECONOMIC CONSIDERATIONS FOR THE NET-ZERO MICROGRID.................................... 11

5.1 Business Case for Net-Zero Microgrid Solutions ...................................................................... 11

5.1.1 Zero-Carbon Dispatchable Generation ..................................................................... 12

5.1.2 Power-Grid Design and Carbon Reduction ........................................................... 14

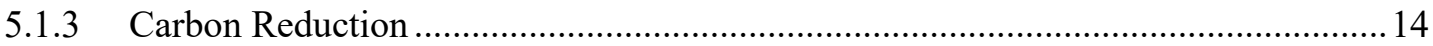

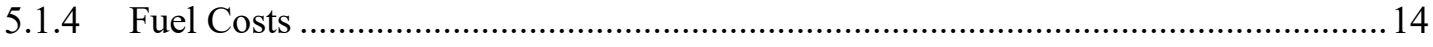

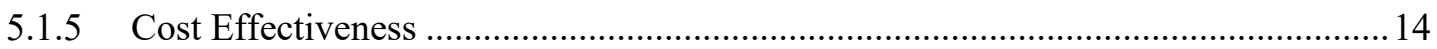

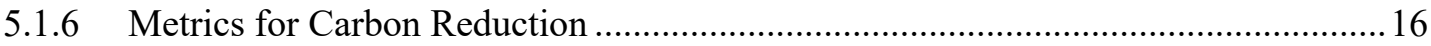

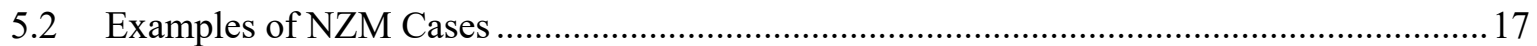

5.2.1 Solar and Some Storage with a Natural Gas Generator.............................................. 18

5.2.2 Solar and Storage with No Natural Gas.................................................................. 19

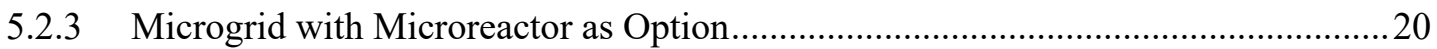

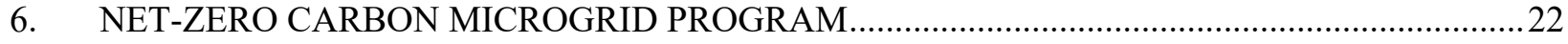

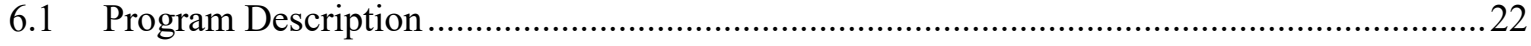




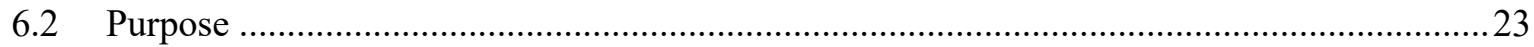

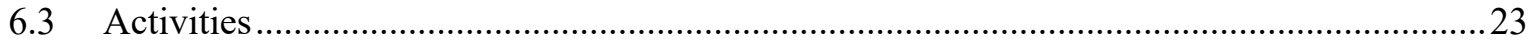

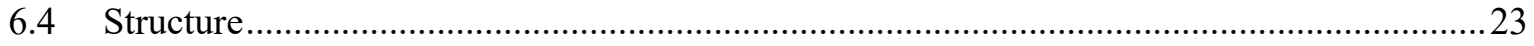

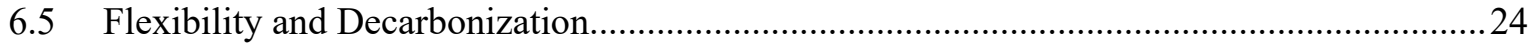

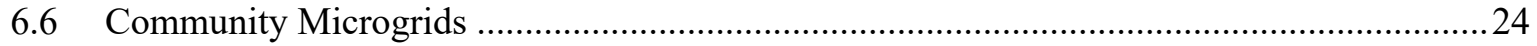

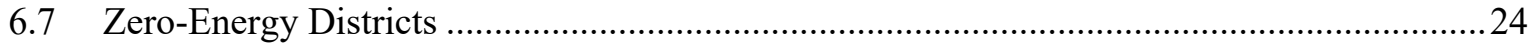

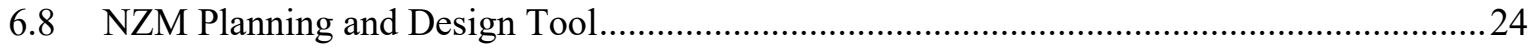

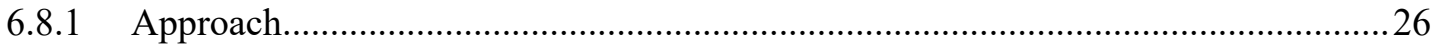

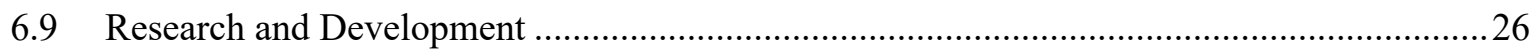

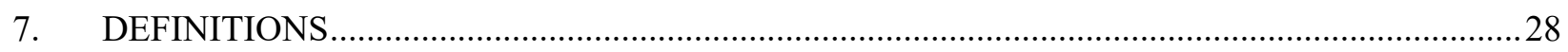

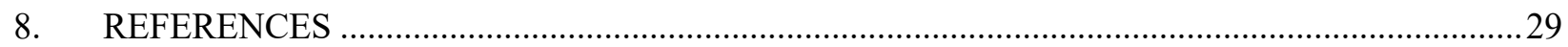

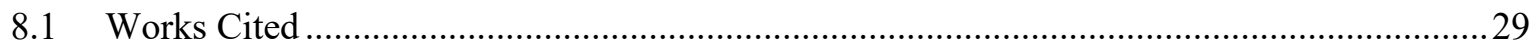

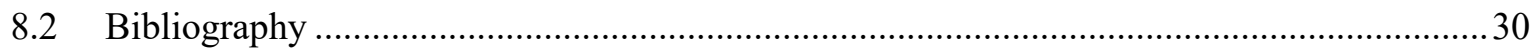

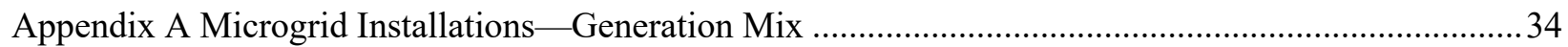

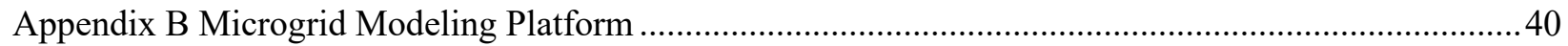

Appendix C Revenue from Markets — New Concepts..........................................................................46

\section{FIGURES}

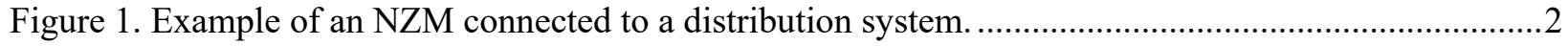

Figure 2. New capacity: generators by fuel type and storage, U.S. national vs microgrids (2020)............6

Figure 3. Interactive chart illustrating the history of natural gas prices (\$ US per million BTU)..............10

Figure 4. Tradeoff between costs and $\mathrm{CO}_{2}$ emissions for a large Californian microgrid.........................12

Figure 5. Optimized electricity dispatch on a spring day that is carbon neutral. .....................................13

Figure 6. Electric load for California microgrid case .......................................................................... 17

Figure 7. Hot-water load for California microgrid case …................................................................. 17

Figure 8. Optimal May dispatch for the microgrid with natural gas, PV, and storage............................18

Figure 9. Optimal May dispatch for the microgrid for peak-load day PV and storage only....................19

Figure 10. Optimal Dispatch to net-zero and revenue from markets by including nuclear energy............21

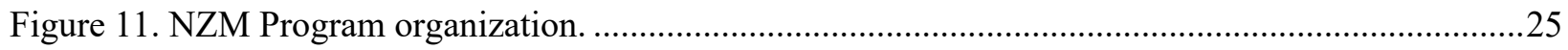

\section{TABLES}

Table 1. Microgrid fuels and storage, cumulative installed capacity (2020).........................................5

Table 2. Estimated annual energy microgrid generation (MWh) by fuel type ..........................................5

Table 3. U.S. utility-scale electricity generation by source, amount, and share of total in 2020 ...............6 
Table 4. Comparison of $1 \mathrm{MW}$ natural gas technology with $1 \mathrm{MW}$ microreactor technology.

Table 5. Cost optimal results.

Table 6. Carbon neutral case: economic and technical results (with just PV and electric storage)

Table 7. Economic and technical results for a net-zero microgrid with PV, storage, and a microreactor..

Table A-1. Microgrid installations, generation by fuel (kw) and storage. .36

Table B-1. Functions and requirements. 42 


\section{ACRONYMS}

BESS Battery energy storage system

CPUC California Public Utilities Commission

DER Distributed energy resources

DOE Department of Energy

EIA Energy Information Administration

GHG Greenhouse gases

IES Integrated Energy Systems

INL Idaho National Laboratory

ITC Investment tax credits

LME Locational marginal emission

NPP Nuclear power plants

NRIC National Reactor Innovation Center

NZC Net-zero-carbon

NZM Net-zero Carbon Microgrid

OE Office of Electricity

PG\&E Pacific Gas and Electric

PJM Pennsylvania-New Jersey-Maryland

PSPS Public-safety power shutoff

PTC Production tax credits

PV Photovoltaic

ROI Return on investment

SMR Small modular reactors

SPV Solar photovoltaic

TIER Tax-incentive emission reduction

VPP Virtual power plant

WTG Wind-turbine generators

ZEC Zero-emission credit 
Page intentionally left blank 


\section{Net-Zero Carbon Microgrids}

The United States is committed to reducing greenhouse gas emissions in 2030 by $50-52 \%$ from 2005 levels. This goal converges with the need to reach at least $80 \%$ clean electricity by 2030 . Net-zero-carbon microgrids (NZMs) can contribute to these commitments by transitioning to renewable and non-carbonbased generation. This report summarizes the current state of microgrids, introduces requirements, and needed advances and analysis to make NZMs pervasive in the time frame of the United States commitments to greenhouse gas reduction.

The microgrid concept was developed to increase the energy security and resiliency in the face of extreme events, and the hosting capacity for local renewable energy resources, for supplying critical infrastructures, such as hospitals, sensitive industries, and research facilities. Originally defined as a group of interconnected loads and distributed-energy resources (DERs) with clearly defined electrical boundaries that act as a single controllable entity with respect to the grid, microgrids could connect and disconnect from the grid to enable them to operate in either grid-connected or islanded modes. Resiliency is achieved by islanding the microgrid when the main grid fails.

\section{NET-ZERO CARBON MICROGRIDS - CONCEPT, STRUCTURE, AND OPERATIONS}

A microgrid is a collection of generation, storage, and loads that are capable of sustaining operations when disconnected (islanded) from the larger grid. A microgrid control system is required in any microgrid to manage optimization of economics when connected to distribution system infrastructure and provide all control capabilities required to maintain stable operation and support critical loads when disconnected. The key difference in an NZM is the replacement of the typical backup generation in the form of diesel or natural gas. The inclusion of more actively controlled DERs and consideration for providing valuable services to the distribution system require that a NZM controller include elements of DER management system (DERMS) and/or coordination with distribution management systems (DMS).

Given the capability to manage DERs, the microgrid concept can be applied to bring net-zero-carbon (NZC), defined as meeting the commitment to reducing greenhouse gas emissions to zero through balancing the emissions produced and emissions removed from the earth's atmosphere. NZC solutions to distribution utilities and customers. A NZM is a combination of DERs, including generation from renewable-energy resources and electricity storage and controllable loads within a microgrid's boundaries. The key to the operation of a distribution grid based on DER is the microgrid controller. An example is presented in Figure 1.

NZC is achieved by supplying the loads within the microgrid boundaries from generation based on renewable energy sources, balanced and firmed by means of electrical storage and aggregations of other DERs, including controllable loads. These loads are calculated to provide demand response. Additional power, if required, can be provided from other clean and dispatchable energy resources.

Figure 1 shows a possible implementation of an NZM that includes only generation from renewableenergy resources, including wind and solar, and generation that does not create greenhouse gases (GHGs). This generation may be based on currently available fuels, such as hydrogen burned in internalcombustion engines or fuel cells, or by nuclear material, used in small modular reactors (SMRs) and microreactors. 


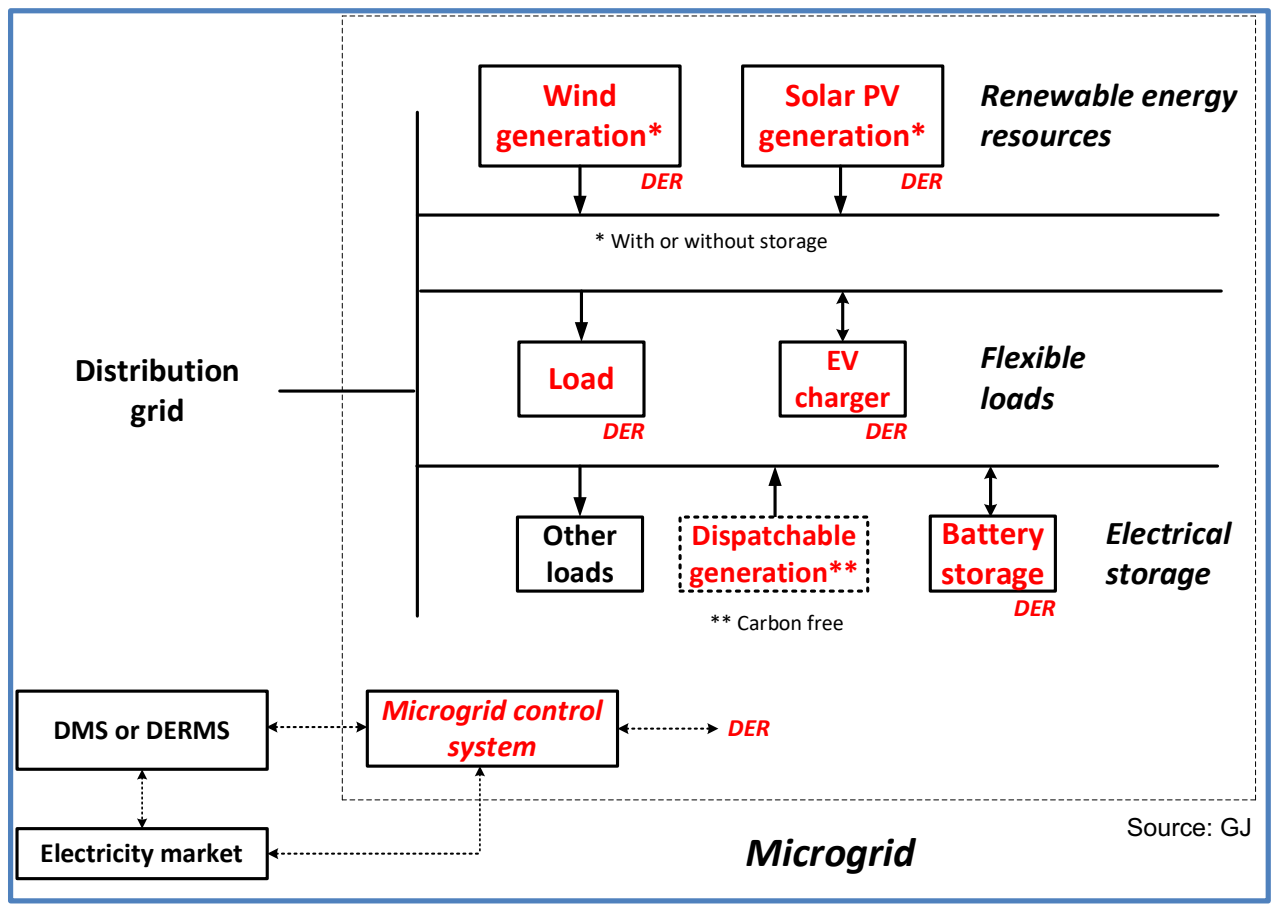

Figure 1. Example of an NZM connected to a distribution system.

\section{Background}

This section introduces important background, definitions, motivations, and high-level requirements for moving forward with needed policy, technology, standards, and research to see serious carbon reduction in microgrids.

The historical motivations of implementing microgrids are based on their capability to enhance grid resilience, stability, and energy security using local energy resources. Additionally, microgrids provide ancillary services to the grid by contributing to voltage and frequency support, lowering the carbon footprint, and matching power quality to end-user requirements.

Today, new motivation for implementing microgrids is related to an accelerated push toward green power generation and a move away from reliance on fossil fuels. Microgrids are seen as a means of achieving NZC in delivering power to consumers and greening distribution grids. Although challenges may be met on the way to achieving the NZC target, the microgrid is a first step toward greening distribution grids, and if a large number of such microgrids are deployed, power distribution can be made increasingly green in the foreseeable future.

\subsection{Role of the Net-Zero-Carbon Microgrid in Meeting Greenhouse Targets}

If NZC power is to be delivered, all sources of power in a microgrid must jointly implement an equivalent NZC power supply, whatever the time frame, including continuously and over a specified length of time in an emergency situation. Energy sources must be green and/or renewable. Today, these sources typically include solar and wind power, to which must be added dispatchable sources of green, carbon-free power. At this time, the only readily available or planned sources of this nature are hydrogen and nuclear power; these sources would be implemented in microgrids in the form of hydrogen fuel cells, hydrogen-supplied internal-combustion engines, or SMRs and microreactors. 


\subsection{Microgrid Design Considerations-Extension to Net-zero-carbon Grids}

Microgrids can be designed for an NZC operation by a proper selection and sizing of the renewable resources - mostly solar photovoltaic (SPV) generators - and the proper sizing of the battery energy storage system (BESS). Wind-turbine generators (WTGs) can also be used. The BESSs can be sized to smooth out short-term SPV power variations and support operation of the microgrid during the night or sustained overcast weather conditions. For a continuous operation at full load over an extended period of time, a green dispatchable generator should be installed.

NZC continuous operation of the microgrid must be defined over a specified period: a day, a week, a month, or a year. This parameter defines the type and size (power and energy) of installed generation and storage. Implementing NZC and allowing islanded operation over a given period requires that the amount of green power drawn from the main grid and of power supplied by green generators be specified.

Examples of the challenges to achieve an NZC operation in distribution grids based on the microgrid concept include: (a) providing firm power over a defined period using a combination of renewable energy resources and storage and (b) displacing the conventional generators in providing resiliency services (backup power).

\subsection{Description of the Operating Modes of a Net-zero-carbon Microgrid}

Microgrids embedded in distribution systems can be operated in either grid-connected or islanded mode.

1. Grid-connected mode. This is the normal mode of operation. The microgrid can be operated continuously within NZC mode by relying on a combination of power produced locally and external renewable-energy resources. If the variability and intermittency of this power is balanced and firmed by means of electrical storage, the power drawn from the electric grid is constant over a given period and thereby set at a negotiated value. The power produced within the microgrid is of an NZC nature.

2. Grid-connected mode, NZC (on average) power operation. If the power drawn from the grid needs to be reduced to zero over a specified duration - typically 1 day, week, or year-NZC operation can be achieved by ensuring that the energy produced locally from renewable energy resources plus available storage is sufficient to supply the loads over the specified duration. This means that power will be drawn from the grid during periods of low production - for example, nighttime in the case of solar-powered microgrids - and returned to the grid during periods of high production, unless the electrical-storage capacity is sufficient to cover the period of low production. The microgrid can also be operated in a net-zero power mode and NZC mode if there is sufficient carbon-free local generation, including renewable-energy resources and generators operating carbon free.

3. Islanded mode. In the event of a blackout or an emergency resulting from extreme atmospheric events, the microgrid will island and supply all or a portion of the load (critical loads). The amount will depend on power-production and storage assets installed within the microgrid boundaries. For short periods, local generation and electrical storage may supply all or a portion of the loadstypically, emergency loads. For longer-duration islanded operation, the microgrid may require a larger source of energy, either more renewable-energy generation combined with a larger electricalstorage system, or a larger fuel-storage system, such as hydrogen tanks.

\subsection{Operating Modes of the Microgrid-Constraints Associated with a Net-Zero-Carbon Operation}

Microgrids typically need a dispatchable source of power to operate, supplied by: 
- The distribution grid or a dispatchable generator in grid-connected mode

- A dispatchable generator in islanded mode.

Today, this generation is provided by a diesel or gas engine or by combined heat and power (CHP), i.e., cogeneration. In the future, it could be a fuel cell (hydrogen) or an SMR. Without a dispatchable generator, the NZM typically cannot island for extended periods of time, and if it islands under exceptional circumstances, it can supply only emergency loads and for a limited time.

NZC can be achieved by minimizing the dispatchable generator in relationship to generation using renewables, storage, and flexible loads. At the same time, an NZM must be capable of islanding for whatever duration is required for resiliency. The tradeoffs for resource balance within the microgrid will vary greatly depending on outage duration. For this reason, in the near term, generators using some form of fossil fuels, in particular natural gas, may be necessary. The approach, then, should be to replace these generators with renewable-energy-sourced generators, with the goal of $80 \%$ renewables by 2030 .

\subsection{Green Credits for NZM}

NZMs provide tangible and intangible outcomes compared to today's microgrids. The obvious driver is the need for GHG reduction. To value GHG reductions policy-based encouragement is required. The differences between the microgrid today and the NZM in the future are highlighted below.

Today the microgrid today typically includes

- A fossil-fuel-driven generator: either one or more diesel or gasoline engines capable of driving an electric power generator to supply up to $80 \%$ of baseload power

- Generation based on renewable energy resources, with a peak rating of up to $80 \%$ of baseload power

- Battery energy storage, with an inverter rated $80 \%$ of baseload power, and a battery with a 3 hour rating at $80 \%$ of baseload power.

In the future NZM configurations are anticipated to be comprised of non-carbon-based generation:

- In islanded mode, under normal operating conditions during the day, the combination of all three energy resources supply the load power

- At night, the battery and the generator operate to supply the load, which allows the microgrid to collect green credits

- In grid-connected mode, the generator does not run, and that percentage of the load is supplied by a combination of solar and battery, which allows the microgrid to collect green credits.

When NZMs are set up to obtain green credits, optimizing the collection of those credits is a consideration for capital expenditure (Capex) and operational expenditure (OpEx). 


\section{MICROGRID GENERATION - FUEL MIX TODAY}

Carbon- and pollution-producing energy sources dominate microgrids today. And the ratio of renewable energy sources for new generation in microgrids is lower than the macrogrid. This section first describes the fuel mix in installed generation in microgrids today. Then, the fuel mix in new generation in microgrids is compared to the fuel mix for new generation in the macrogrid. It is evident that microgrids are not transitioning to carbon-free fuels at the same rate as the grid overall. This indicates a need for changes in the approach to microgrid planning and design, as advocated by the NZM Program.

\subsection{Installed Capacity}

Distributed fossil-fuel generation accounted for more than $80 \%$ of cumulative installed microgrid capacity in 2020, as shown in Table 1.

Table 1. Microgrid fuels and storage, cumulative installed capacity (2020). ${ }^{1}$

\begin{tabular}{|l|c|c|c|}
\hline \multicolumn{1}{|c|}{ Fuel Type } & $\begin{array}{c}\text { Generation } \\
(\mathbf{k W})\end{array}$ & Ratio & Fossil \\
\hline Diesel & 2,475 & $40.1 \%$ & $40.1 \%$ \\
\hline Natural Gas: CHP & 1,316 & $21.3 \%$ & $21.3 \%$ \\
\hline Natural Gas & 1,037 & $16.8 \%$ & $16.8 \%$ \\
\hline Solar PV & 475 & $7.7 \%$ & \\
\hline Hydro & 286 & $4.6 \%$ & \\
\hline Fuel Cell* & 175 & $2.8 \%$ & $2.8 \%$ \\
\hline Wind & 95 & $1.5 \%$ & \\
\hline Fuel not specified & 311 & $5.0 \%$ & \\
\hline Total & $\mathbf{6 , 1 7 1}$ & $\mathbf{1 0 0 . 0 \%}$ & $\mathbf{8 1 . 0 \%}$ \\
\hline Storage & 200 & & \\
\hline
\end{tabular}

* Stationary fuel cells in the U.S. in microgrids almost all depend on natural gas as the fuel. While they can use hydrogen, almost none of them are able to get hydrogen piped to their facilities. These should be included in the fossil-fuel portion of microgrid generation.

\subsection{Energy Sources}

The energy sources for microgrid generation are predominantly diesel and natural gas $(82 \%)$, as shown in Table 2.

Table 2. Estimated annual energy microgrid generation (MWh) by fuel type.

\begin{tabular}{lccc|}
\multicolumn{1}{c}{ Fuel Type } & $\begin{array}{c}\text { Generation } \\
\text { (MWh) }\end{array}$ & Ratio & Fossil \\
\hline Diesel & $1,084,107$ & $9.6 \%$ & $9.6 \%$ \\
Natural gas & 454,381 & $4.0 \%$ & $4.0 \%$ \\
Natural gas: CHP & $6,342,280$ & $55.9 \%$ & $55.9 \%$ \\
Fuel cell & $1,383,540$ & $12.2 \%$ & $12.2 \%$ \\
Hydro & $1,002,736$ & $8.8 \%$ & \\
SPV & 831,509 & $7.3 \%$ & \\
Wind & 249,712 & $2.2 \%$ & \\
Total & $11,348,264$ & $100.0 \%$ & $81.6 \%$ \\
\hline
\end{tabular}


This compares to an energy mix for all electric generation in the U.S. in 2020 of $60 \%$ fossil fuels (coal, natural gas, and petroleum), 20\% renewable (wind, solar, geothermal) energy, and $20 \%$ (carbon free) nuclear, as shown in Table 3.

Table 3. U.S. utility-scale electricity generation by source, amount, and share of total in $2020{ }^{2}$

\begin{tabular}{|l|c|c|}
\hline \multicolumn{1}{|c|}{ Energy Source } & Billion kWh & Share of Total \\
\hline Fossil fuels (total) & 2,427 & $60.6 \%$ \\
\hline Natural gas & 1,624 & $40.5 \%$ \\
\hline Coal & 773 & $19.3 \%$ \\
\hline Petroleum & 17 & $0.4 \%$ \\
\hline Nuclear & 790 & $19.7 \%$ \\
\hline Renewables (total) & 792 & $19.7 \%$ \\
\hline Wind & 338 & $8.4 \%$ \\
\hline Hydropower & 291 & $7.2 \%$ \\
\hline Solar & 91 & $2.3 \%$ \\
\hline Biomass & 56 & $1.4 \%$ \\
\hline Geothermal & 17 & $0.4 \%$ \\
\hline Total, all sources & $\mathbf{4 , 0 0 7}$ & $\mathbf{1 0 0 . 0 \%}$ \\
\hline
\end{tabular}

Thus, the proportion of energy used in microgrids generation is higher than the macro grid: $82 \%$ compared to $60 \%$.

\subsection{New Generation-Microgrids vs Macrogrid}

The proportion of renewables in new generation in microgrids is much lower than in the macrogrid. New generator capacity for the macrogrid has a greater proportion of renewable-energy resources than microgrids: $72 \%$ to $25 \%$, as shown in Figure 2. New capacity for microgrids continues to be dominated by natural gas. The proportion of natural gas in new capacity for microgrids is $62 \%$, compared to $17 \%$ for new capacity in the macrogrid. Storage for both the macro- and microgrids is being added in about the same proportion. The inference can be drawn that additional renewables in the macrogrid are supported by storage to manage intermittency whereas in microgrids, storage, together with fossil-fueled generators, have a role in islanding and resiliency.

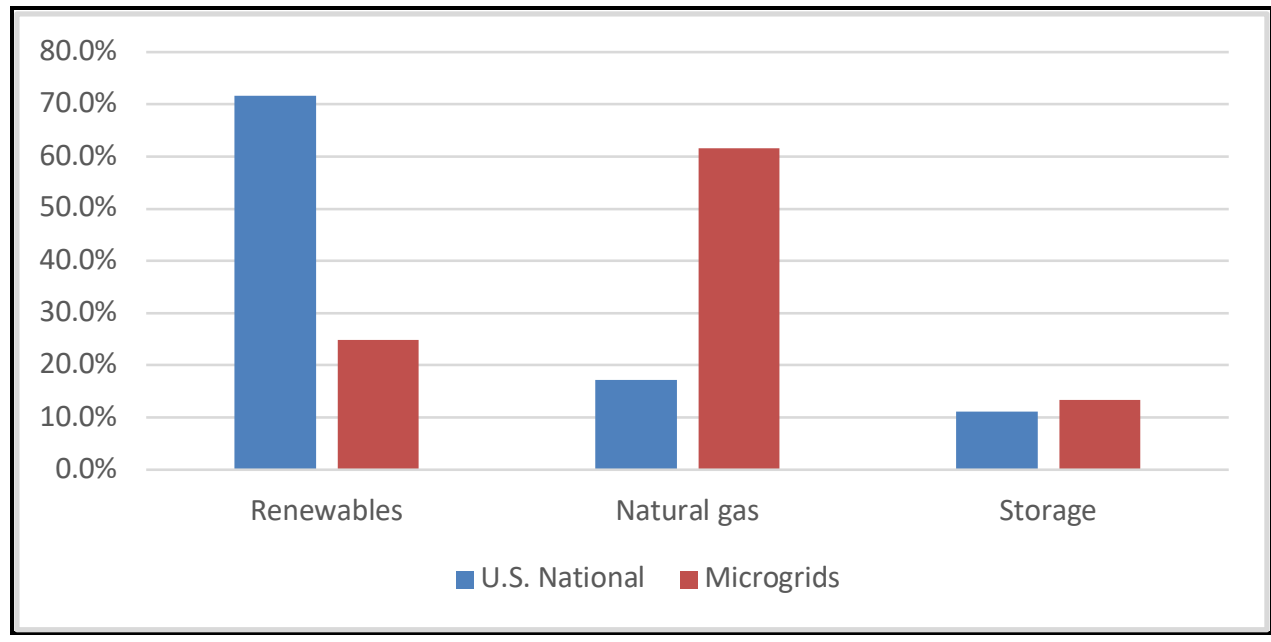

Figure 2. New capacity: generators by fuel type and storage, U.S. national vs microgrids (2020). 
Although microgrids provide less than $0.2 \%$ of U.S. electricity in 2020, as their number and size increase, the inclusion of renewable energy resources in the generation mix will become more and more important for reaching goals of net-zero carbon in the electric sector.

\subsection{Microgrids for Resiliency}

In the 1970s, what are today called microgrids were CHP-based facilities, with the CHP running continuously and providing heat and electric power. Diesel generators were used for backup power during outages. The New York City blackout of 2003 and Hurricane Sandy in 2012 led to increased focus on resiliency and backup power that is dedicated to critical loads and could be islanded from the grid. This led to microgrids that included (diesel and natural gas) generators, inverter-based (solar and storage) resources, and controllable loads within a defined boundary.

CHP-based facilities sized below $50 \mathrm{MW}$ are considered microgrids. The trend in CHPs is toward smaller and smaller facilities (DOE CHP database). These are mostly being connected to distribution networks. Needless to say, fossil-fuel generators remain the dominant power source within microgrids, mostly because their primary role is to provide resiliency. This is evident from the deployment of diesel generators for resiliency in response to the public-safety power shutoff (PSPS) in California.

\subsubsection{Pacific Gas and Electric Resiliency Plans}

In response to blackouts and PSPS due to wildfires, Pacific Gas and Electric (PG\&E) plans a major expansion of its use of mobile generators (2020). The $\$ 173$ million plan includes $\$ 94$ million in reservation fees to place a hold on hundreds of $2 \mathrm{MW}$ diesel generators for quick deployment. The California Public Utilities Commission (CPUC) approved this plan despite the high GHG-emissions profile and the "potential health risks" for local residents.

Although PG\&E is allowed to use mobile diesel generators, at least for this year, the CPUC does not consider this to be a long-term solution to provide multiday power backup for wildfire- and blackoutprone communities. Zero-carbon solutions are difficult to achieve. Providing 2-4 days of backup power for a $10 \mathrm{MW}$ community microgrid from solar and batteries would require a large and redundant battery capacity - up to $350 \mathrm{MWh}$ of batteries for $10 \mathrm{MW}$ of load - and require up to 90 acres of photovoltaic (PV) solar to reliably charge them over that time. Natural gas reciprocating engines with nitrogen oxide lower emissions to $1 \%$ of those of a Tier 2 diesel engine. This points toward alternative fuels for generators and solar with batteries as options favorable toward a zero-carbon solution.

\subsubsection{Distribution Microgrids and PSPS}

During PSPS events, "distribution microgrids" can support frequently impacted communities by powering circuits on distribution networks in corridors that serve critical and shared resources such as fire and police stations, medical facilities, grocery stores, gas stations, and government facilities. Generation at these substations that runs on diesel fuel should be replaced with renewable generation; communities in California that are served by these substations demand it. In the face of wildfires, these communities presently have no choice other than to accept diesel generators in order to avoid extended outages. Replacing fossil-fuel generators at these priority substations should be pursued as a priority for microgrid deployments. The NZM is ideal for these applications.

The top priority of microgrid regulatory proceedings in California is to reduce impact on customers from PSPSs that are implemented by the utilities to reduce wildfire risks. Only temporary deployments of microgrids with diesel generators are financially viable now, and none meets clean-energy advocates' call for including customer-owned DERs. For 2020, in the face of an intense wildfire season, high cost and long time to deploy were obstacles to the placement of microgrids. This made it necessary to rely on temporary fossil-fuel-powered generators and focus on microgrids later. As Southern California Electric Director of Energy Policy Shinjini Menon put it: 
The best case scenario [for microgrids] would cost about thirteen times more

than alternative solutions and would not include clean energy technologies, so we have decided not to move forward with a microgrid deployment for the 2020 wildfire season. ${ }^{3}$

The Microgrid Planning and Design Tools for NZM, described in this report, can facilitate an alternative solution. Distribution microgrids can be installed at priority substations. These distribution substations can be disconnected from the grid (using the switchgear at the point of common coupling), and creating a local distribution grid - that is, a community microgrid. The NZM should provide the same functionality as existing microgrids where natural gas and diesel generators predominate. Dispatchability is essential, and the transition to islanded operations needs to be seamless.

Further, it should be noted that the NZM offers advantages for resiliency where there are risks of disruption to the fossil-fuel supply. This may be significant when a microgrid operates in islanded mode for extended periods of time. 


\section{THE INTEGRATION OF RENEWABLE ENERGY IN MICROGRIDS}

Today, microgrids are not following the current trends towards decarbonization in the macrogrid. As centralized generation on the macrogrid trends toward energy from wind and solar farms, and new generation is connected on distribution networks, renewables in microgrids and aggregated in a virtual power plant (VPP) will become more and more important for reaching goals for the reduction in GHGs.

An NZM can be achieved by increasing the proportion of generation from renewable energy and storage relative to fossil-fueled generation within the microgrid. Any renewable-energy solution must address requirements that are fulfilled now by diesel and natural gas generation for

- Frequency and voltage control

- Sufficient spinning reserve

- Sufficient active and reactive power supply

- Peak shaving and load levelling

- Load sharing between generators

- Fault current provision.

These requirements cannot be fulfilled completely by generation from intermittent energy resources, particularly those related to firm capacity and energy, such as spinning reserve, peak shaving, and load levelling. These requirements can, however, be fulfilled by electric energy storage systems. A certain level of synchronous generation is necessary today to compensate for volatility and provide inertia. However, these functions can, to some extent, be built into inverter-based renewable generation and storage.

Return on investment (ROI) can be maximized by using resources in the microgrid for the provision of grid services, in aggregation with other renewable-energy resources on the grid. The Energy Information Administration (EIA) indicates the recent global average carbon-intensity factor for electricity generation is $475 \mathrm{~g} \mathrm{CO}_{2} / \mathrm{kWh} .27 \mathrm{GW}$ of traditional grid generation operating at $50 \%$ capacity (a happy medium between a $25 \%$ solar capacity and $75 \%$ natural gas capacity estimate), emits an estimated 56 MMTs of $\mathrm{CO}_{2}$ emissions per year. Assuming this is eventually replaced with renewablescontaining microgrids with a conservative $30 \%$ reduction in $\mathrm{CO}_{2}$ emissions over the baseline gridprovides a 16.8 MMT $\mathrm{CO}_{2}$-emissions-reduction estimate from all of the installed or planned microgrids. For a relatively small deployment, the potential is promising, and it improves if these microgrids use primarily renewable-energy generation and battery storage. ${ }^{3}$

\subsection{Trend Towards Distributed Generation}

Expected capacity additions for centralized generation are compared to expected new DER-capacity additions on an annual basis, globally, from 2020 to $2030 .{ }^{4}$ Although many DER assets are deployed as redundant power or backup generation, DER deployments overall-including conventional and renewable distributed generation, flexible resources, and electric vehicles (EVs) - are expected to outpace centralized generation in all regions during the forecast period.

By 2030, new DER capacity additions will be nearly twice the capacity on an annual basis as centralized generation systems. For conventional utility-industry paradigms, this trend would be significantly problematic. However, if DER can be orchestrated by market participants at scale, these assets can enhance the value of energy and power infrastructure across the value chain and activate a broader stakeholder ecosystem that creates and receives value in dynamic markets.

As DERs grow, integration platforms are required to manage their aggregation and network and market operations. Distributed-energy resources management systems, starting with microgrid controllers, enable expanded control, interoperability across heterogeneous grid elements, and applications for 
provisioning grid services and participation in markets. This is the key to the success in fully realizing the value of DERs. However, these solutions are also aimed at a common purpose: supporting a more-nimble, sustainable, and customer-centric energy future.

\subsection{Natural Gas-Price Volatility and Security of Supply}

A historical chart of natural gas prices from 2012 to 2021 is presented as Figure 3.

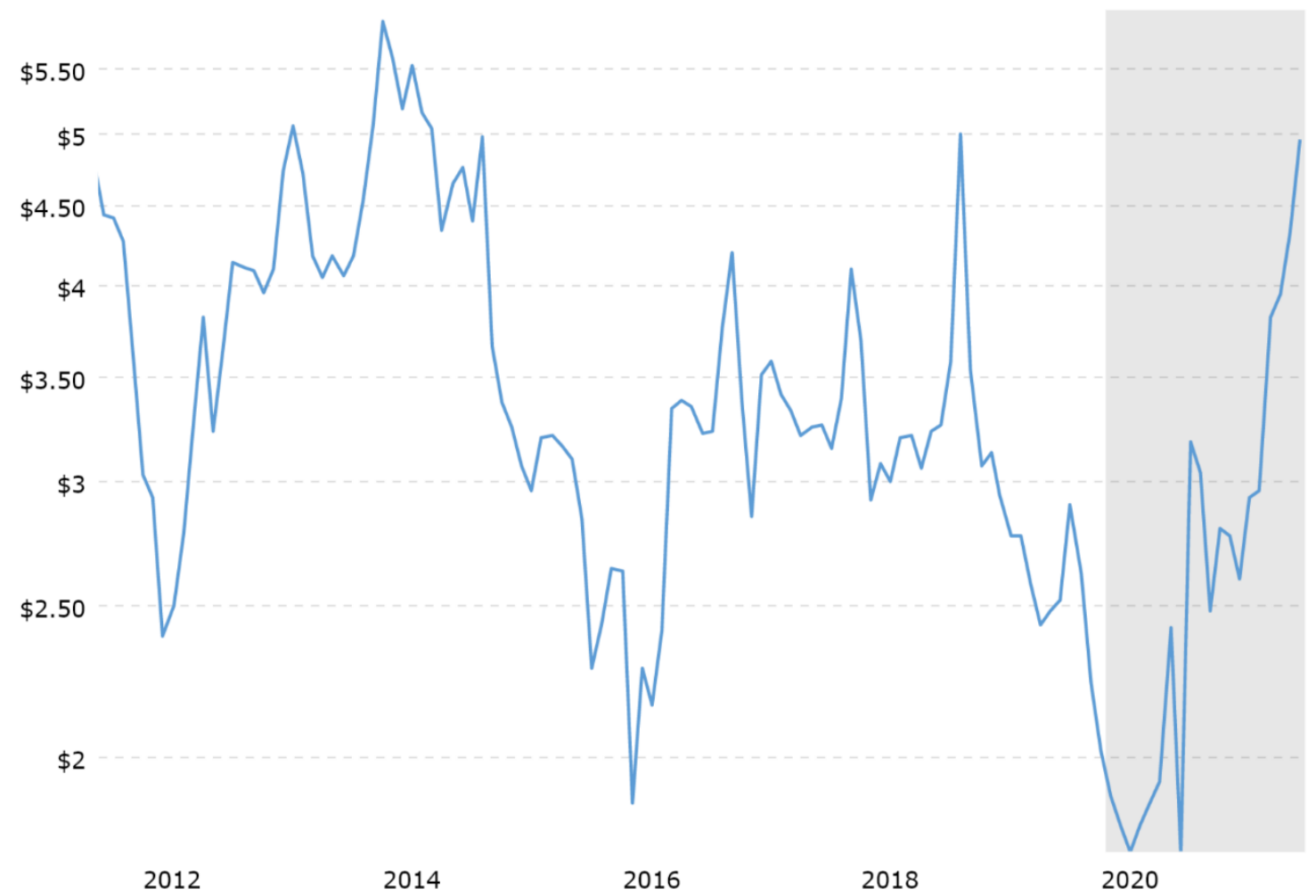

Figure 3. Interactive chart illustrating the history of natural gas prices (\$ US per million BTU). 


\section{ECONOMIC CONSIDERATIONS FOR THE NET-ZERO MICROGRID 5.1 Business Case for Net-Zero Microgrid Solutions}

A major difficulty in making the business case for NZM is to put an appropriate price or compensation on the benefits of net-zero operation, including GHG-emission reductions and other advantages inherent in the replacement of fossil fuels. As is well known, among the benefits of microgrids in general is the reliability and the power quality supplied, together with the resilience of the energy supply. Quantification of these benefits is difficult and dependent on many uncontrollable parameters, such as cost of the generation and storage equipment. Benefits may vary over time.

Establishing a business case when there are a number of generation assets with very different capital and operating costs is difficult; these costs are evolving, based on availability, ability to manufacture at scale, and technology development. The business case for NZM can be understood in terms of the definition of net-zero carbon (see def.) and by recognizing the concept of timeframe or time duration of net-zero operation of the microgrid - that is, under what conditions the operation of the microgrid can be defined as NZC.

Instantaneous operation can be carbon free when generation and consumption within the microgrid are balanced; this would exclude any operation of fossil-fuel-based generation, except possibly under emergency conditions, by exception. This also means that in an islanded operation, the microgrid may go black - for example, when energy storage is depleted - unless fossil-fuel backup generation is dispatched. Over a specified timeframe (e.g., 1 month or 1 year), as is defined in net-zero buildings or communities where the assumption is that the microgrid would get carbon credits when exporting green power to the grid, allowing fossil-fuel generation to operate when required by conditions, such as an unanticipated absence of solar and wind or heavy loading.

The NZM does not need fossil-fuel-based generation for dispatchability and stability. These can be achieved with a sufficient combination of renewable generation and storage that is balanced with demand response and can import power from the grid as needed should the energy-storage system be depleted. Conventional generation is not needed to ensure stability; the energy storage system can play this role, providing a stable voltage and frequency reference in islanded mode. There should be no stability issue in grid-connected mode if the controller is properly designed and coordinated with the grid.

The cost of the NZM — configured with resources for sustainable operations - will most probably be higher than those dependent on fossil-fuel-based generation (see Figure 4). Oversizing of renewable generation, greater amounts of storage, and the enabling energy-management system result in a cost premium to achieve the carbon reductions that are valued goals of public policy. 


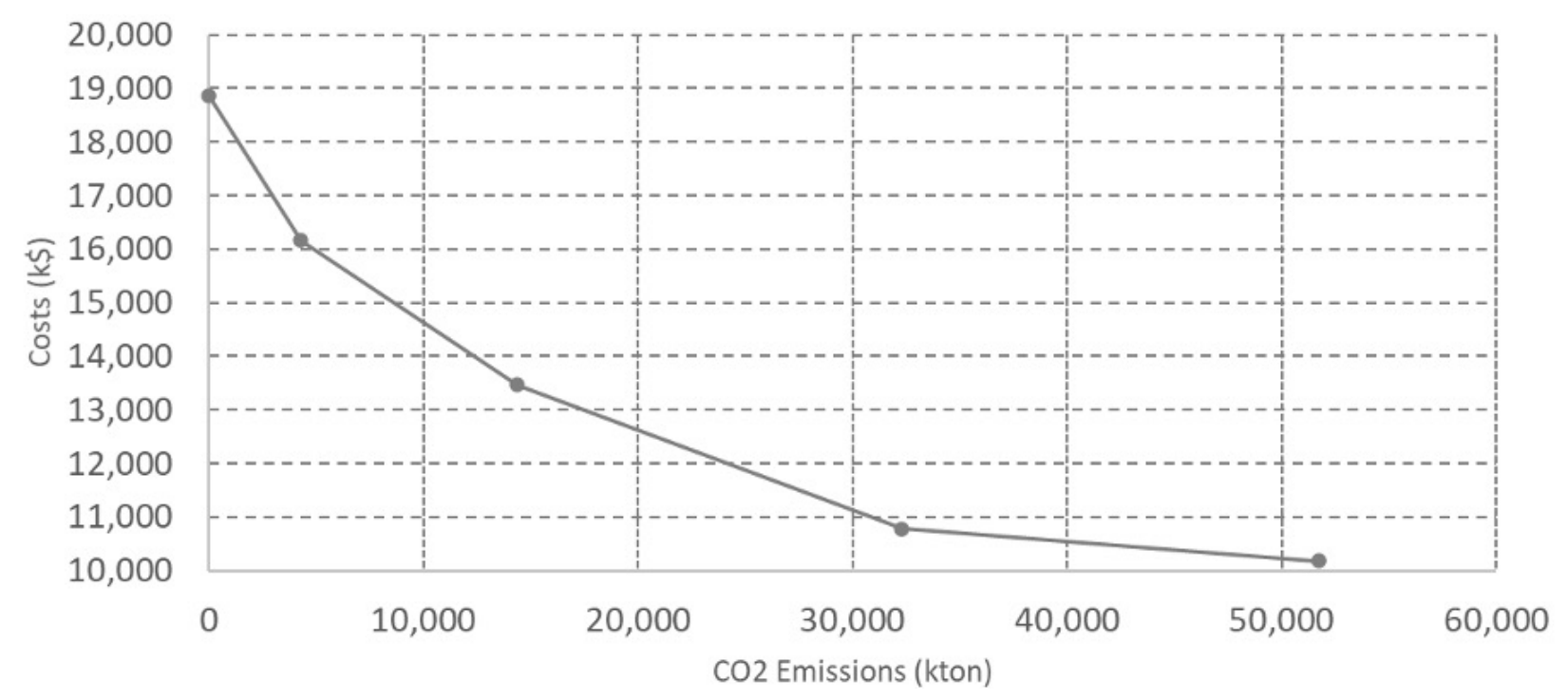

Figure 4. Tradeoff between costs and $\mathrm{CO}_{2}$ emissions for a large Californian microgrid.

To achieve carbon neutrality with just PV and electric storage, the price for energy would need to increase by $80 \%$.

\subsubsection{Zero-Carbon Dispatchable Generation}

Zero-carbon dispatchable generation includes generation using hydrogen as a fuel, and power generation based on either fuel cells or internal-combustion engines (with designs for new fuels) and SMR and microreactors. The technology for zero-carbon generators is currently in various stages of development. Of these technologies, microreactors have the highest probability for near-term deployment: 3 to 4 years for either remote or grid-connected pilot projects in the field.

Microreactors, PVs, and electric storage can be used together to achieve carbon neutrality. Storage can include power that can be sold as dispatchable electricity to the utility. Other technologies, such as large hot- or cold-water storage tanks, could be considered as well, increasing system efficiency. Figure 5 illustrates the use of storage to balance generation sources with loads and market demands from the connected utility. Results are shown for a large Californian microgrid with PVs, electric storage, and natural gas engines. Total electric load maximum is $17 \mathrm{MW}$. 


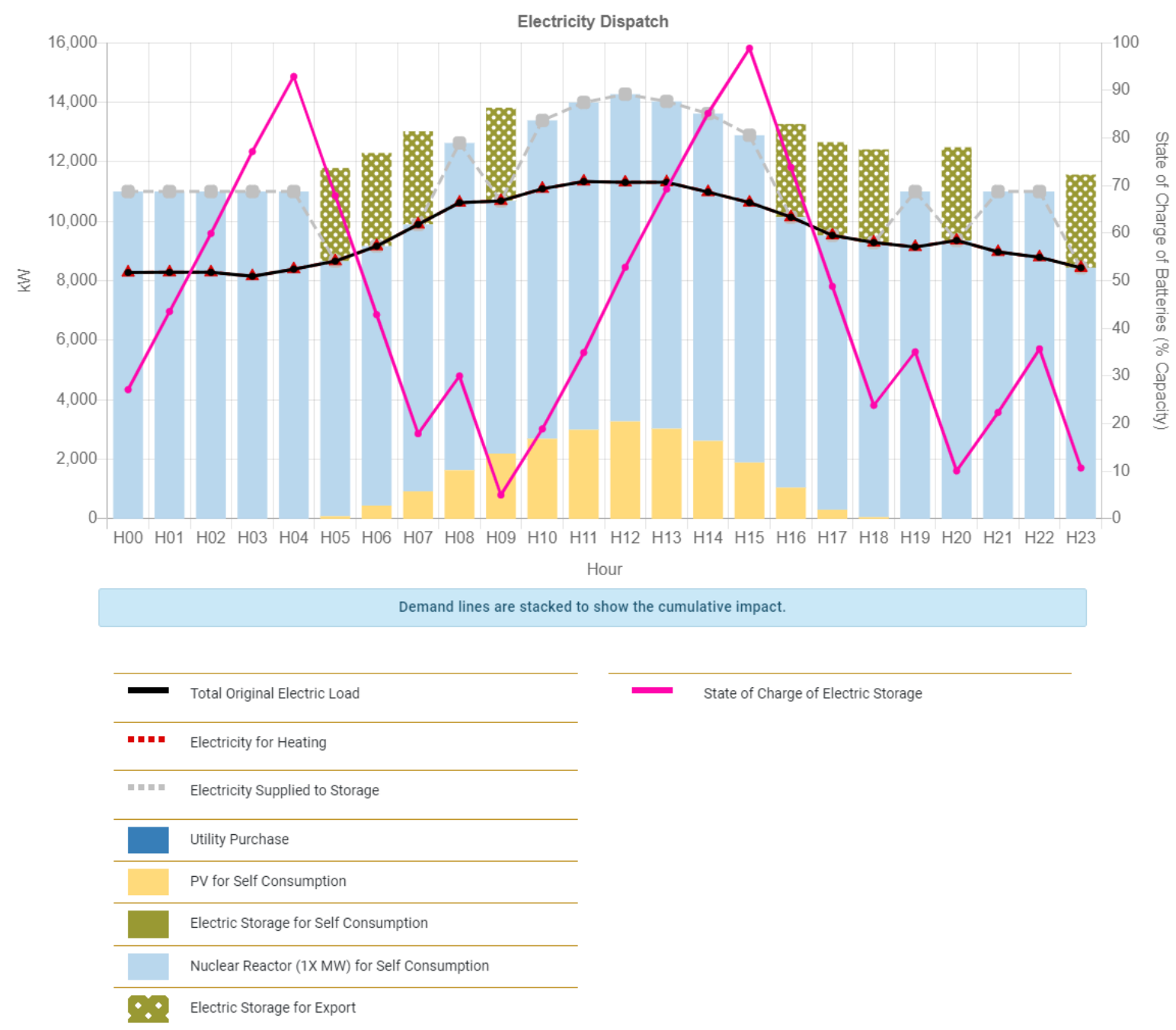

Figure 5. Optimized electricity dispatch on a spring day that is carbon neutral.

Once SMRs are technically ready for deployment - meeting high standards for safety and operational flexibility - their costs will be greater than those for grid-supplied power or for microgrids with conventional and renewable generation. Also, increased costs for long-term storage facilities of waste fuel need to be considered. For these reasons, incentives might be necessary to obtain the benefits of net-zero operation and sustainability from the secure energy supply for generation that SMRs provide. On the plus side, fuel costs will be lower.

SMRs and microreactors, developed with advanced-reactor technology, are being facilitated by National Reactor Innovation Center (NRIC) and the Cross-Cutting Development Integrated Energy Systems (IES) Program. These will have new technological and operational features important for safe and economical operation in NZC microgrids:

Advanced reactors currently under development will offer compelling features that enable new applications of nuclear IES. In addition to providing electricity for the grid, IES incorporating advanced nuclear technologies can provide heat, electricity, and other energy products, such as hydrogen and synthetic fuels, to microgrids, industrial complexes, military installations, remote industrial operations, commercial parks, and transportation hubs. Applications of IES may 
include thermal-, electrochemical-, or chemical energy storage to dynamically

balance generation and load, such as balancing nuclear electricity generation

with non-dispatchable renewable generation and cyclical electrical loads. ${ }^{5}$

\subsubsection{Power-Grid Design and Carbon Reduction}

Provided with renewable generation and energy storage, properly sized generation and storage assets, and optimized controllers, including generation and load forecasting, an NZM can significantly reduce its the carbon footprint and emissions of a microgrid. ${ }^{3}$ However, the carbon emissions of NZM must be monitored and verified to ensure that the reductions are real and quantifiable. Emissions could also be monitored on a continuous basis to limit emissions in real time.

NZM operation depends on microgrid design, the amount of generation resources and storage available at any given time, and load flexibility, including the extent of curtailments and optimization algorithms that limit carbon emissions. Design criteria need to go beyond economics to meet the social imperatives for carbon reduction in the face of climate change. This may require financial compensation for additional capital and operating costs resulting from a NZC operation.

\subsubsection{Carbon Reduction}

Mechanisms should be provided for minimizing carbon emissions at the microgrid design stage. Design optimization should take into account the configuration and operating modes of all assets in the planning of the microgrid and a calculation and analysis over a year of their combined impact on carbon emissions. Carbon-emission reduction should be included as priorities, or at least options in the design for resiliency and reliability of the microgrid. An NZM may come with higher costs. ${ }^{a}$

\subsubsection{Fuel Costs}

The business case for NZM depends largely on the relative cost of energy from dispatchable generation in microgrids. Today, dispatchable generators are largely fueled by natural gas or diesel. The cost of natural gas is currently low for the most part, and natural gas is available for most microgrids, apart from those in remote areas. Diesel is a higher-cost fuel, but available for remote microgrids.

The transition to NZM requires substitution of dispatchable fossil-fuel generators by generators with renewable-energy sources such as hydrogen or PVs. Microreactors can also play a role. Those technologies must be balanced with storage and flexible loads. However, although the marginal cost of renewable generation is very low, its initial cost and the cost of the required storage are relatively high. The transition to NZM can be accomplished by configuring microgrids that maintain balance and dispatchability with renewable generation. The design of these microgrids would typically result in a higher relative cost of energy delivered to loads.

\subsubsection{Cost Effectiveness}

The installation and operating costs of NZMs should be optimized around the DERs that are within their boundaries, prioritized at minimal GHG-emission levels. These costs may not be competitive with natural gas or diesel. However, the NZM should be configured and operated to be competitive after financial incentives for carbon reduction are applied in economic analyses for ROI calculations.

\subsubsection{Incentives-NZM with dispatchable conventional generation}

\section{Tax Credits for GHG Reductions in Comparison to Microgrids with Conventional Generation}

Section 45Q of the Internal Revenue Code offers a tax credit that varies from just under $\$ 12$ to $\$ 50$ for each metric ton of carbon captured and sequestered, depending on the timing and type of project.

\footnotetext{
a For example, an optimal microgrid design for carbon reduction may require a fourfold increase in solar PV capacity and a similar or larger increase in energy storage capacity.
} 


\section{Tax Credits for Microgrids}

The Microgrid Act was introduced in the U.S. House of Representatives on April 13, 2021. ${ }^{6}$ This bill would allow a new tax credit for investment in a qualified microgrid, defined as an electrical system that incorporates a microgrid controller, includes equipment that is capable of generating not less than $4 \mathrm{~kW}$, and not more than $50 \mathrm{MW}$ of electricity, operating in connection with the electrical grid and as a single controllable entity with respect to such a grid, and operating independently (and disconnected) from such grid. For qualified microgrids that begin construction prior to 2025 , the credit would be $30 \%$.

\section{Microgrid Tariffs}

In January 2021 the CPUC adopted microgrid rates, tariffs, and rules for large investor-owned electrical corporations. These microgrid rates, tariffs, and rules are intended to facilitate the commercialization of microgrids pursuant to Senate Bill $1339 .^{7}$

In the same decision, CPUC authorized the Microgrid Incentive Program, with a \$200 million budget to fund clean-energy microgrids in support of the critical needs of vulnerable communities impacted by grid outages. The program would also test new technologies or regulatory approaches to inform future action.

\section{Microgrid Services Tariff: Hawaii}

The Hawaii Public Utilities Commission approved a microgrid-services tariff, effective May 27, 2021, which sets the definitions and process for customer and hybrid systems to interconnect with the Hawaiian electric grid. ${ }^{8}$ The tariff applies to customer and hybrid microgrids-i.e., microgrids in which an operator may combine utility infrastructure and customer infrastructure to supply electricity to microgrid members during an emergency. The tariff recognizes that microgrids can provide gridinteractive solutions using Internet connections for utility-grid flexibility and resilience.

\section{Carbon Tax and Penalties for GHG Emissions on Generation with Fossil Fuels}

Efforts to put a price on GHG emissions are growing, with carbon prices now in effect in twelve states. ${ }^{9}$ In California, the SB 1339 legislative requirement allows the California Air Resources Board to certify distributed-generation technologies that would have an immediate impact on local air quality by replacing diesel generators with cleaner technologies like fuel-cell systems. Carbon-tax changes impose costs on competitiveness, dulling the advantage of conventional generation — natural gas and diesel, in particular.

\subsubsection{Incentives-zero carbon with microreactors}

Incentives would allow the immediate deployment of microreactors as economic and competitive dispatchable generation in NZMs. These incentives could allow microreactors to replace non-dispatchable renewable generation in many configurations, avoiding unnecessary oversizing of renewable generation with conventional, dispatchable generation and replacing conventional generation. Microreactors would compensate for carbon reduction as well as enhanced resilience through sustainability of fuel supply. Table 4 provides a comparison of the characteristics of a typical natural gas generator and a microreactor of the same generation capability. ${ }^{5}$ 
Table 4. Comparison of $1 \mathrm{MW}$ natural gas technology with $1 \mathrm{MW}$ microreactor technology.

\begin{tabular}{|l|c|c|}
\hline \multicolumn{1}{|c|}{ Category } & $\begin{array}{c}\text { Natural Gas Engine } \\
(\mathbf{1} \text { MW) }\end{array}$ & Microreactor (1 MW) \\
\hline Investment costs $(\$ / \mathrm{kW})$ & $2,900,000$ & $11,200,000$ \\
\hline Lifetime (years) & 15 & 50 \\
\hline Electric efficiency $(\%)$ & 26 & 1.7 \\
\hline Heat to Power ratio $(\mathrm{kWH} / \mathrm{kWE})$ & 1.6 & 3 \\
\hline
\end{tabular}

\section{Tax Credits and Direct Spending}

Strategies for creating economic incentives that encourage the integration of SMR and microreactors are summarized below:

- Production tax credits (PTCs): extension of PTCs for wind, solar, biomass, and hydropower resources to microreactors

- Investment tax credits (ITCs): extension of ITCs for solar, offshore wind, and fuel cells to microreactors

- Direct payments in place of tax credits allowing ITCs and PTCs to take direct payment instead of tax credits.

Note: An ITC of $30 \%$ or a PTC at $\$ 25 / \mathrm{MWH}$ for microreactors as zero-emitting capacity would "hypercharge" the deployment of SMR and microreactors and their integration with renewable-energy in microgrids.

\subsubsection{Subsidies by states}

States have subsidy programs for nuclear power plants (NPPs) that make up for unrecovered costs for participation in energy markets. These payments could be funded by surcharges on electricity customers who participate in clean-energy markets previously restricted to renewables. These are often in the form of zero-emission credits (ZECs) for nuclear power production. While ZEC programs differ, they generally offer an NPP credits against above-market prices for the power they produce based on "an established social cost of carbon" that reflects the environmental cost of emissions. ZECs could be created for microreactors in microgrids.

\subsubsection{Metrics for Carbon Reduction}

If NZMs are to qualify for the incentives listed above, it is necessary to verify actual reductions in carbon from their operations. A number of options are available to verify the impact of emerging microgrid designs. For new, innovative technologies that have a potential to impact carbon reductions, environmental technology verification, using the ISO 14034 standard, can verify the technology's performance and its potential impacts before it is deployed. An environmental technology verification would give users independently validated, high-quality data to enhance decisions about such technology implementation and its impact, including the potential to support carbon-reduction goals.

Measurement and verification could be included in contract requirements within such instruments as energy-savings performance contracts. The International Performance Measurement and Verification Protocol is often applied to verify energy conservation and efficiency savings; it could be applied to microgrid-related savings and include associated carbon-emission reductions verification. 
Whatever the approach, as microgrid implementation rapidly increases and intersects with carbon emission-reduction targets, optimal design considerations and impact verification are needed to achieve the desired results.

\subsection{Examples of NZM Cases}

This hypothetical NZM case located in Southern California with a maximum available space for PVs of $275,000 \mathrm{ft}^{2}$. The microgrid would have conventional, 24/7 operation and would be capable of islanding for three days. Purchases from the utility, PVs, electric storage, natural gas generators, as well as microreactors are possible options to supply energy. The load requirements are shown in Figure 6 and Figure 7. The hypothetical site is referred to as the California microgrid throughout this section.

We consider three cases: one, natural gas generation with some solar and storage; two, solar and storage only; and three, including a microreactor with solar and storage.

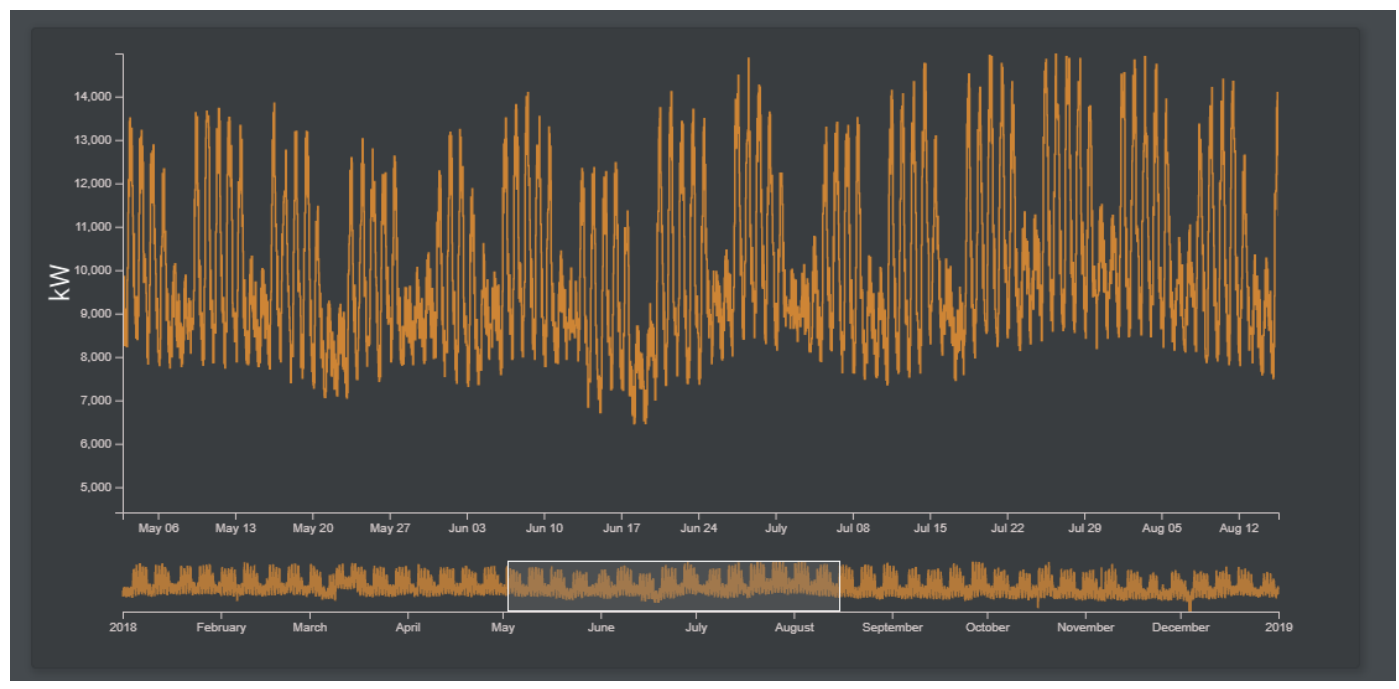

Figure 6. Electric load for California microgrid case.

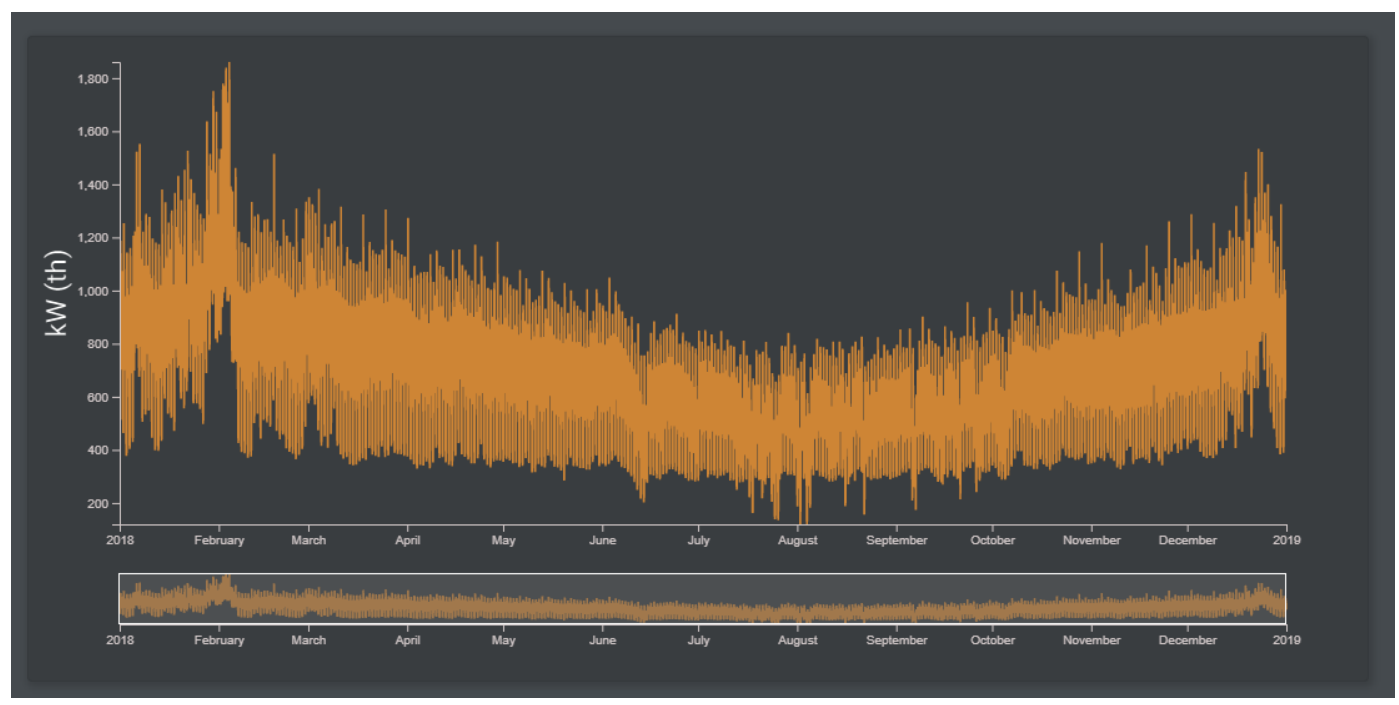

Figure 7. Hot-water load for California microgrid case.

\footnotetext{
b Typical microgrid loads and configuration provided by Michael Stadler.
} 


\subsubsection{Solar and Some Storage with a Natural Gas Generator}

This case considers sales from the electric storage system to create a dispatchable resource for the utility. This case also considers the realistic space constraint of $275,000 \mathrm{ft}^{2}$ for PVs. The mathematical optimization was set to cost minimization; costs are summarized in Table 5. All heating in this case is served by the natural gas CHP system.

Table 5. Cost optimal results.

\begin{tabular}{|l|c|}
\hline \multicolumn{1}{|c|}{ Category } & Result \\
\hline Installed PV (kW) & 4,811 \\
\hline Installed electric storage $(\mathrm{kWh})$ & 1,800 \\
\hline Installed natural gas engines $(\mathrm{kW})$ & 10,000 \\
\hline Annual energy costs $(\mathrm{k} \$)$ & 10,175 \\
\hline Annual onsite $\mathrm{CO}_{2}$ emissions (kton) & 51,852 \\
\hline
\end{tabular}

Optimal dispatch for the system on a typical day in May in Southern California is illustrated in Figure 8. For optimal dispatch the microgrid selects PV, electric storage, and natural gas engines to be cost minimal. The microgrid optimizes costs also by reducing utility purchases and limiting them to avoid high demand charges (flattened blue bars).

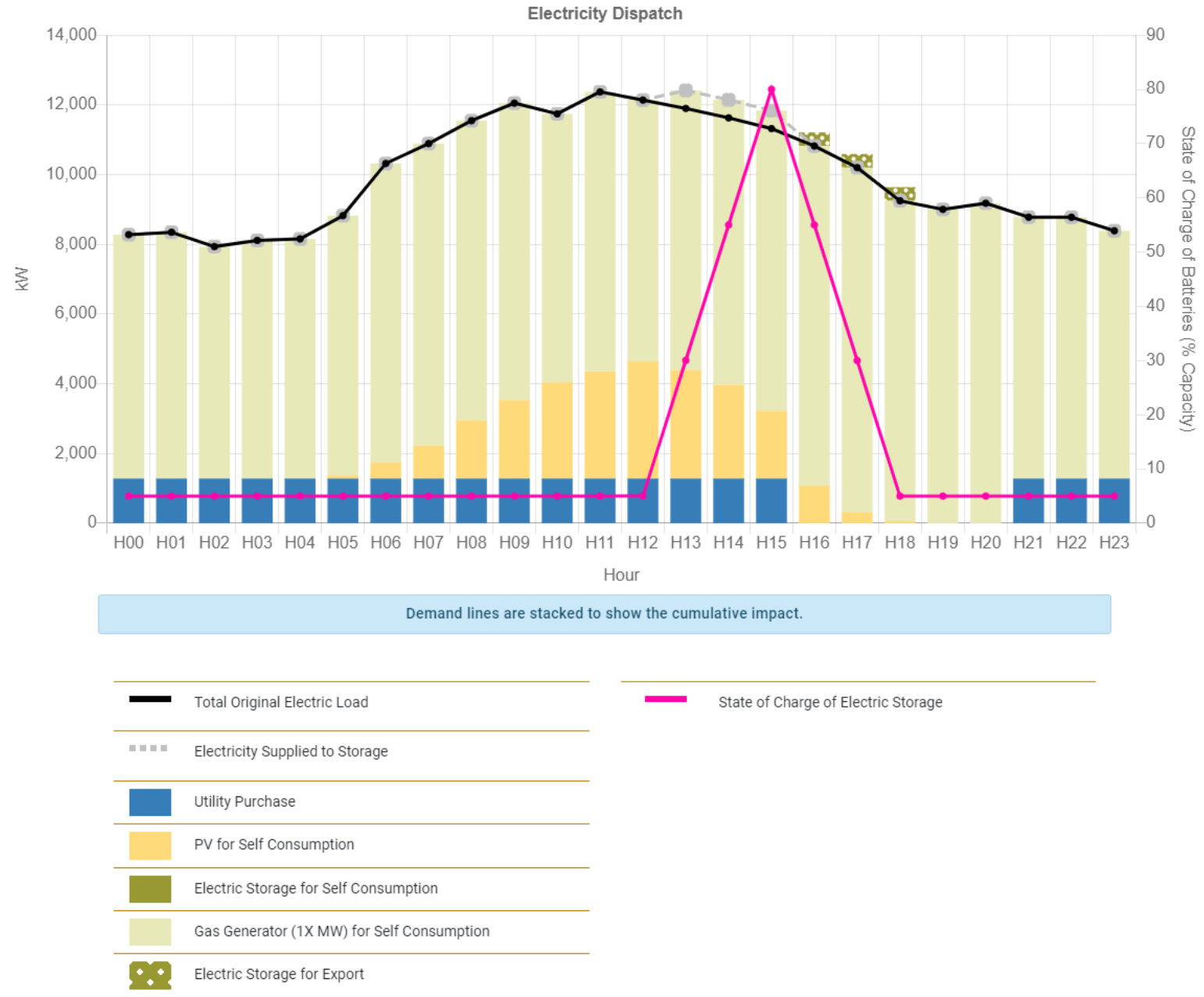

Figure 8. Optimal May dispatch for the microgrid with natural gas, PV, and storage. 


\subsubsection{Solar and Storage with No Natural Gas}

This case would be optimized for net zero (see def.). Thus, no natural gas generator could be used, and the system must be capable of islanding for 3 days to be carbon neutral. This case requires significantly more space for PVs and violates the space constraint of 275,000 $\mathrm{ft}^{2}$ for this site (Table 6).

Table 6. Carbon neutral case: economic and technical results (with just PV and electric storage).

\begin{tabular}{|l|c|}
\hline \multicolumn{1}{|c|}{ Category } & Result \\
\hline Installed PV & $73,500 \mathrm{~kW}$ \\
\hline Installed electric storage & $160,000 \mathrm{kWh}$ \\
\hline Installed natural gas engines & $0 \mathrm{~kW}$ \\
\hline Annual energy costs & $\$ 18,854,000$ \\
\hline Annual onsite $\mathrm{CO}_{2}$ emissions & $0 \mathrm{kton}$ \\
\hline
\end{tabular}

Note that with only the renewable resources an enormous amount of PV and electric storage needs to be installed to achieve carbon neutrality. The electric storage allows sales to the utility, and this creates an additional revenue stream through electric sales to the utility during expensive hours between 5 and 7 PM. The system can be run completely independent of the utility, if needed, but for economic reasons, electricity sales are favorable. Heating loads are covered by existing boilers. Dispatch on a peak-load day is shown in Figure 9.

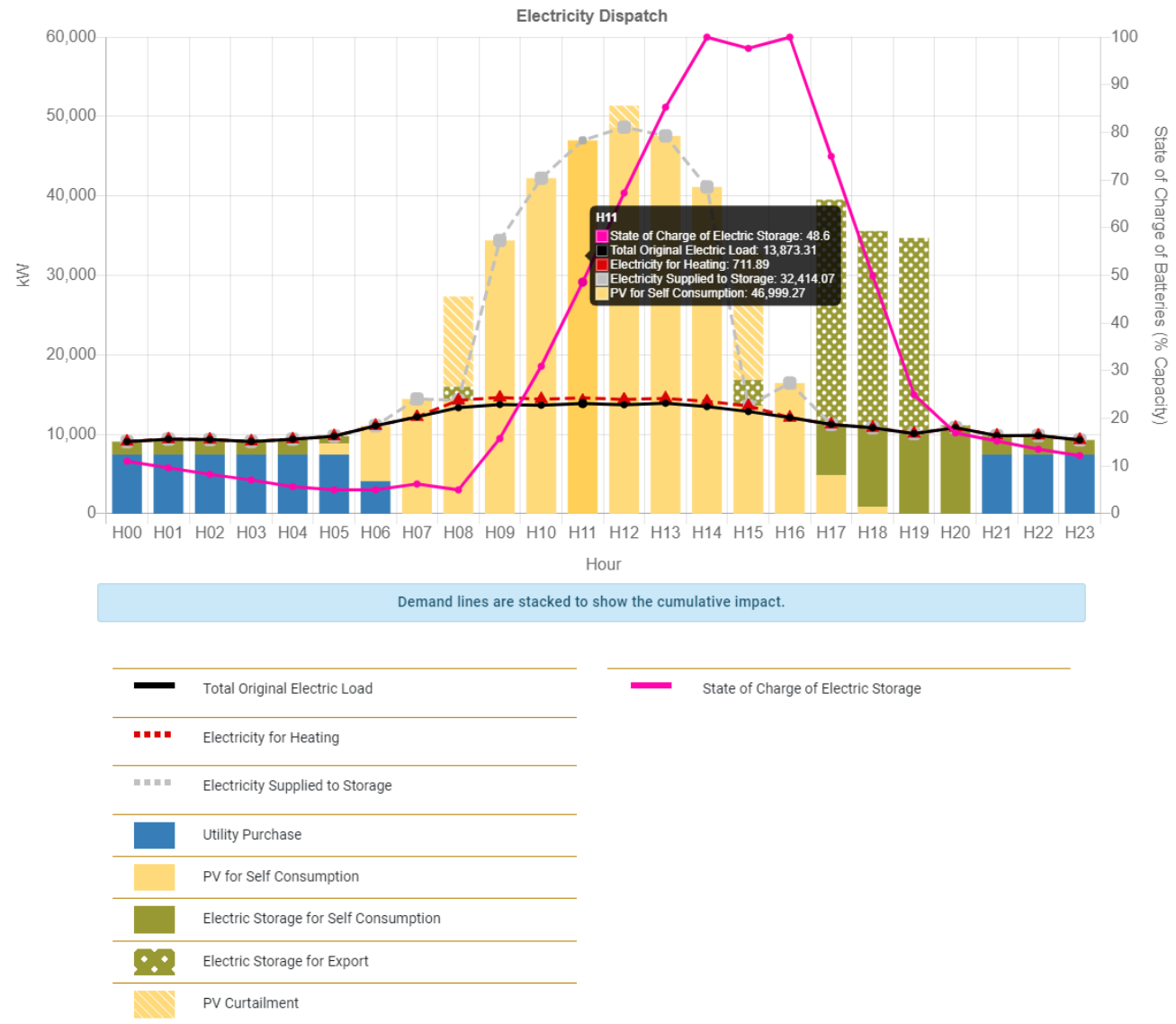

Figure 9. Optimal May dispatch for the microgrid for peak-load day, PV and storage only. 


\subsubsection{Microgrid with Microreactor as Option}

This run also considers sales from the electric-storage system to create a dispatchable resource for the utility and the realistic space constraint of $275,000 \mathrm{ft}^{2}$ for PV. The optimal results show that all heating in this case is served by the microreactor system. Table 7 provides cost-benefit results for such a system, but the results do not consider societal and environmental impacts of long-term storage of the used reactor fuel.

Table 7. Economic and technical results for a net-zero microgrid with PV, storage, and a microreactor.

\begin{tabular}{|l|c|}
\hline \multicolumn{1}{|c|}{ Category } & Result \\
\hline Installed PV & $4,671 \mathrm{~kW}$ \\
\hline Installed electric storage & $14,400 \mathrm{kWh}$ \\
\hline Installed microreactors & $11,000 \mathrm{~kW}$ \\
\hline Annual energy costs & $\$ 13,468,000$ \\
\hline Annual onsite $\mathrm{CO}_{2}$ emissions & $0 \mathrm{kton}$ \\
\hline
\end{tabular}

Optimal dispatch for a microgrid in California on a peak-load day in May with PV, electric storage, and a microreactor as an option to achieve carbon neutrality is illustrated in Figure 10. Electric storage is used to sell electricity to the utility.

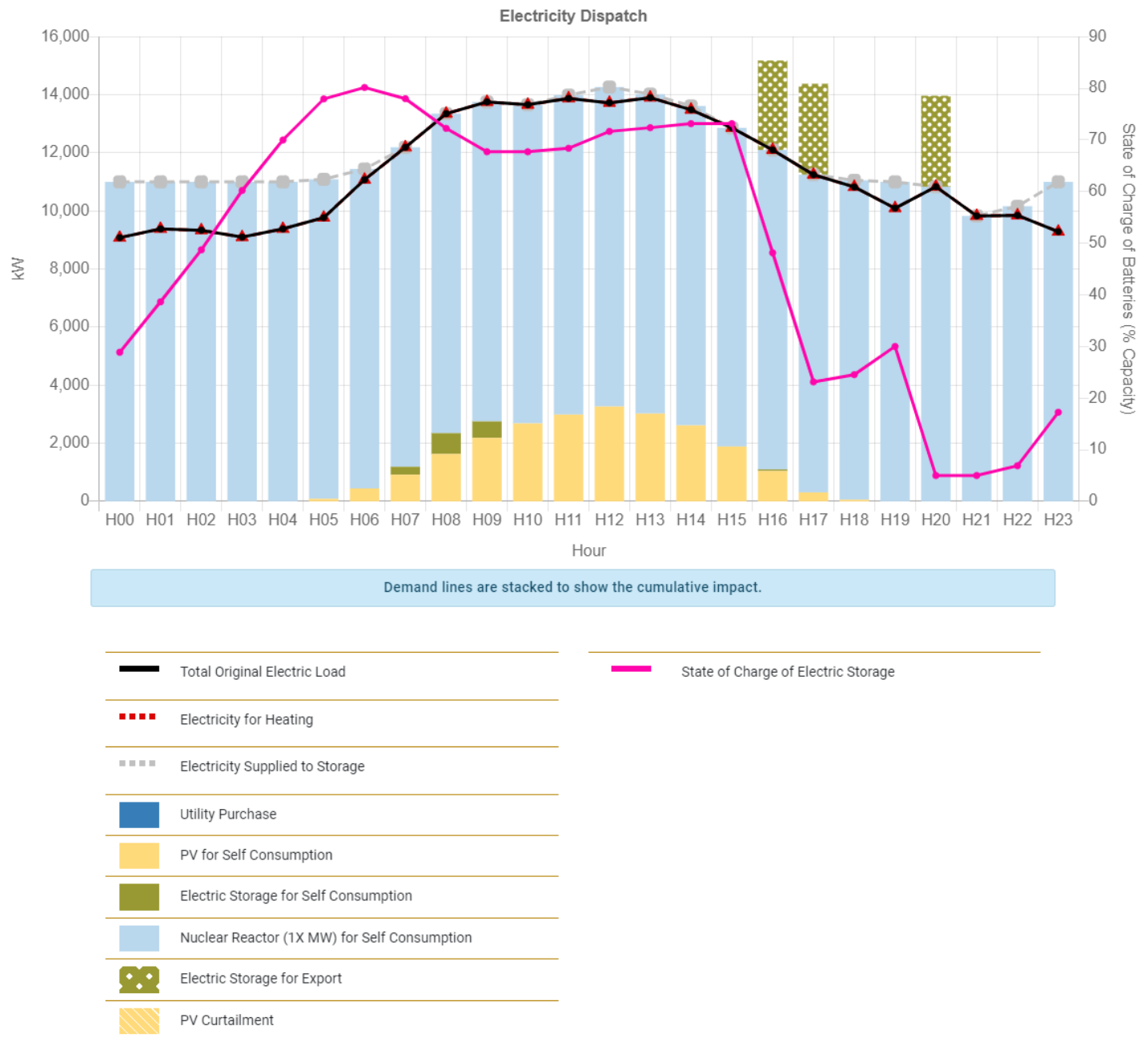


Figure 10. Optimal Dispatch to net-zero and revenue from markets by including nuclear energy.

Market designs are proposed to recognize the value of carbon reduction. Participation in these markets would be a source of revenue to owners and operators of the NZM. Prominent among the concepts behind these market designs are:

- Integrated clean-capacity market. Based on a design concept by Kathleen Spees, a 3-year forward market would attract the optimal resource mix for reliability and state policy goals. ${ }^{10}$

- "Emissionality" offsets. Emmissionality is financed partially by selling carbon emissions that will be displaced over the microgrid's lifetime. These transactions will not take the customary form of renewable-energy credits that average out that value over time; rather, carbon offsets would be directly related to the power grid to which the project is connected. ${ }^{11}$

- Locational marginal emissions involves direct clean-energy deployment at sites with the highestvalue potential to reduce the carbon impact. ${ }^{12}$ See Annex E, "Revenue from Markets-New Concepts," for further descriptions.

The economic feasibility of NZM depends on whether power markets value $100 \%$ clean energy. 


\section{NET-ZERO CARBON MICROGRID PROGRAM}

The capabilities of the NZM Program at INL are described with particular attention to

- NZM planning and design platform for modeling microgrids with a high content of renewable energy

- Simulation of microgrid solutions that are modeled for renewable generation with low emissions

- Feasibility studies

- Pilot projects in the field-test laboratory

- Policy and program support for stakeholders - i.e., policy makers, standards bodies and regulators.

The NZM Program at INL is being funded by Department of Energy's (DOE's) Office of Electricity (OE) to research carbon-free microgrid solutions that offer the benefits of clean energy and enhanced resilience to critical infrastructure and underserved communities in the U.S. and around the globe.

\subsection{Program Description}

The NZM Program was established to produce the cross-cutting research needed to accelerate removal of carbon-emitting generation from microgrids. Microgrids do and will increasingly function in many key roles in security and resilience for critical loads, electrification of infrastructure, and support of distribution and the bulk electric grid. Reduction of the carbon footprint of microgrid designs is an imperative if the U.S. is to achieve its GHG-reduction goals in the drive toward an NZC economy.

The program will establish a clear structure for coordination with the DOE-OE federal manager to manage the technical direction, activities, and milestones measuring the effectiveness of the program. The NZM Program will include the following:

- Applying new generation from renewable energy on distribution networks

- Designing zero-carbon microgrids, VPPs, and other aggregations placed optimally to integrate these resources into the grid and markets

- Reducing the prevalence of fossil-fuel generation dominated microgrids, currently more than $86 \%$ of total generation

- Innovating with SMRs and microreactors to arrive at the ideal dispatchable resource for a NZC microgrid

- Working with regulatory and standards stakeholders to support compliance with standards and understanding and resolving regulatory barriers.

With the accelerated push toward green electric power generation, the implementation of specialized microgrids is an effective approach to provide NZC power to consumers and to green distribution grids. These microgrids use the same basic principles as conventional microgrids and are based on an energymanagement system that implements an NZC operation at all times, whether in grid-connected or islanded mode. This program deals with issues that must be addressed to transition the conventional microgrid to an NZC microgrid, which lowers the microgrid's carbon footprint to zero while preserving its other attributes. These include enhancing grid resilience and stability and energy security using local energy resources, providing ancillary services to the grid, and matching the power quality to the end-user requirements.

The new issues that must be addressed include the provision of the microgrid loads with NZC electric power at all times, including in islanded operation for extended periods of time. This mode of operation requires the inclusion of NZC dispatchable generators in the power-generation portfolio. 


\subsection{Purpose}

The purpose of the program embraces:

1. Configuring a microgrid with NZC power generation. This requires that all sources of power within the microgrid boundaries jointly form an equivalent NZC power supply, whatever the time frame, including continuously and over a specified time in an emergency situation. Energy sources must be green and/or renewable. These sources today include solar and wind power, balanced using an adequate amount of energy storage, to which is added dispatchable energy sources providing green, carbon-free power.

2. Developing net-zero dispatchable power supplies. These electric-power sources can be based on green hydrogen, in the form of hydrogen fuel cells or hydrogen-supplied internal-combustion engines, and nuclear power, in the form of SMRs.

3. Extending the NZC power microgrid concept. With the push to electrification in a number of societal and industrial sectors, new opportunities arise for the implementation of NZC systems, from net-zero energy communities to electric-vehicle charging station.

\subsection{Activities}

Key research and development activities required to implement net-zero microgrids include:

1. Designing and deploying the net-zero microgrid renewable energy power supply. A high penetration of renewable-energy systems requires the selection, sizing, and combination of generators (wind and solar, specifically) to meet the load requirements and an appropriately sized electricity-storage system to balance variability and intermittency. Storage may take a number of forms beyond electrical (batteries), including thermal storage and load management. Battery energy-storage systems can be sized to smooth short-term renewable-power variations and to cover operation of the microgrid at night. For multiday outages, the microgrid must rely on dispatchable generation.

2. Designing and deploying the net-zero microgrid dispatchable power generators. These generators are required for sustained operation of the microgrid in islanded mode, but can also serve in normal, gridconnected mode. In addition, these generating systems can be configured for multiple uses. A hydrogen-based generation system can include a storage systems that can provide a balance of renewable-energy resources. The nuclear-reactor-based system can be used to produce hydrogen or store energy in the form of heat.

3. Designing and deploying net-zero systems for electrification. The NZM concept can be used to supply power to specialized applications. These extend to the electrification of infrastructure at multiple levels.

\subsection{Structure}

The program is structured around the following three areas of research and development expertise:

1. Net-zero microgrid dispatchable power supplies. This work requires teams with expertise in hydrogen and nuclear systems and related areas.

2. Balancing renewables using electricity storage. This work requires teams with expertise in energystorage systems of various types, including combinations of types, and renewable-energy resource power-conversion systems. The key to successful integration is the electronic inverter serving as a grid interface, which not only ensures efficient power conversion of renewable- and clean-energy sources, but also provides the required flexibility and ancillary services.

3. Extension of the net-zero microgrid concept to applications ranging from community microgrids to commercial and industrial microgrids to critical infrastructure to transportation to military bases. 
This work requires teams with expertise in different and unrelated fields and types of microgrids. A key to successful integration is the interaction between the microgrid and the distribution grid and distribution-system operator.

\subsection{Flexibility and Decarbonization}

Microgrids have a flexible architecture for deploying DERs in a variety of configurations for multiple scenarios and customers. The NZM Program aims for a Microgrid Planning and Design Tool that can be used for topology, economics, and operation of microgrids and as a framework for policy and regulatory decisions. With respect to their wide range of potential topologies and end uses, NZMs offer considerable flexibility for fulling their role for the decarbonization of energy systems. Displacing fossil-fuel generation will result in substantial reductions in life-cycle emissions.

\subsection{Community Microgrids}

The NZM Program will deliver a model for community microgrids that can easily be used for by underserved communities. ${ }^{\mathrm{c}}$ It will be a decision-making tool for planning and designing microgrids that goes far beyond the models available today. Most importantly for community microgrids, the program offers possibilities for maximizing renewable generation and storage and minimizing GHG emissions.

There is no reason for community microgrids to have higher harmful emissions than the power provided by the local utility. These microgrids need not be dependent on diesel and natural gas fuels. They can offer resiliency and environmental justice without bringing harmful emissions; in fact, they can reduce them.

\subsection{Zero-Energy Districts}

Urban districts may be able to improve energy cost-effectiveness by leveraging characteristics of NZM for load diversity, scale, and coordinated participation in markets for ancillary grid services. In zero-energy districts, NZM can also coordinate generation and load, along with functions such as load diversity and coordinated participation in markets for ancillary services. Thus, the research in the NZM Program will explore the role of microgrids in urban zero-energy districts and quantify the costeffectiveness and benefits to communities, especially those that are underserved and without high levels of resiliency.

\subsection{NZM Planning and Design Tool}

The NZM Planning and Design Tool is the core capability of NZM Program (Figure 11). The NZM at INL develops a decision-making tool for microgrid planning and design that will optimize renewable generation and storage and minimize GHG emissions, as well as provide alternatives for technology, economics, and finances.

The NZM Planning and Design Tool has unique GIS capabilities for identifying "geographic proximity" and "data, indices, and screening tools" for disadvantaged communities. 


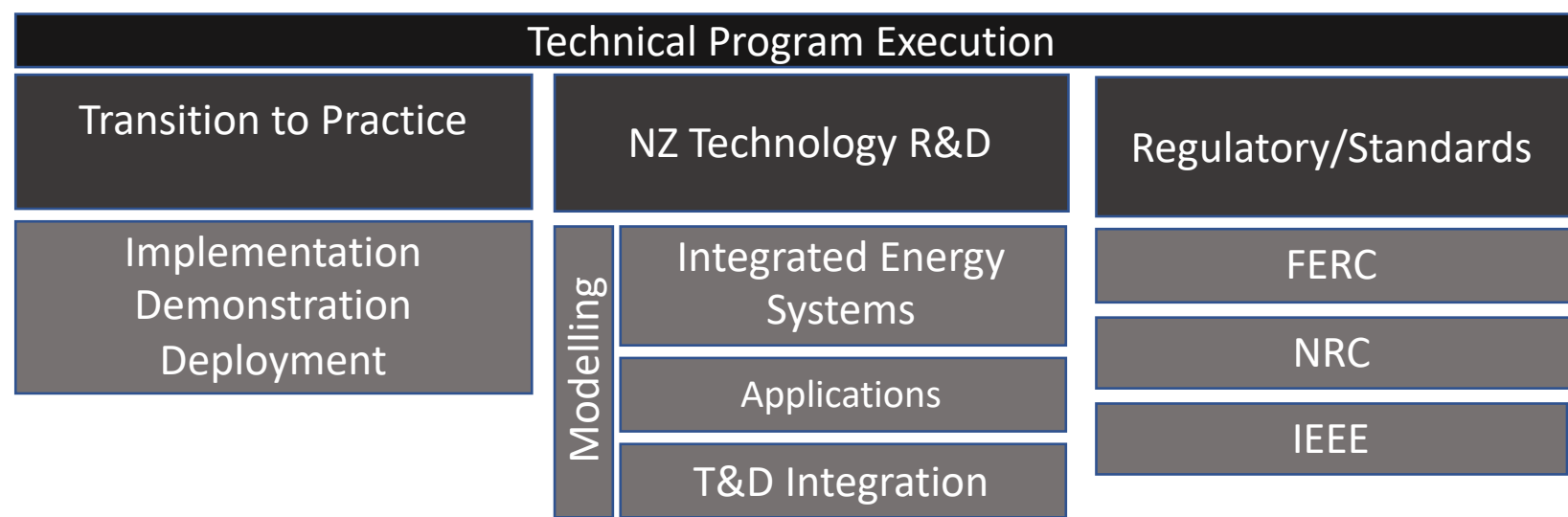

Technology Program Coordination

Advanced Reactor Technologies

Department of Defense
Vehicle Technology /

Transportation

Storage

Battery Hydro
Renewable Energy

Water/Solar/Wind/Thermal

Hydrogen

Fuel Cells

Figure 11. NZM Program organization.

The NZM Program will deliver a modeling tool built on a state-of-the art platform that has a wide range of capabilities, including power systems and connections, tariffs of local utilities, and ROI (the financial dimension). Today, microgrid planning and design tools are disconnected, meaning that they do not integrate economics with power flow. They are not usable outside of the research space and cannot be scaled to encourage investment. Moreover, they do not take GHG emissions into account.

The NZM seeks to integrate all these features in one platform, combining it with easy-to-use databases (including integration with utility databases and a geographical information system [GIS]). The NZM is a complete program that will ensure market penetration for renewables, all while minimizing GHG emissions.

The NZM model will deliver ROI for microgrids of many types and sizes. This offers the ability to show the "bankability" that is needed to attract investors and developers. This is already included in the package, but now metrics for GHG emissions are part of the solution. The metrics for GHGs will be helpful in objectively measuring actual emissions for purposes of incentives that might be available from the administration's climate-change programs, such as subsidies and tax credits for carbon-free solutions.

INL will develop the Net-Zero Microgrid Design Platform based on the XENDEE microgrid platform, ${ }^{\mathrm{d}}$ which is a comprehensive modeling tool for microgrid planning and design with applications for a wide range of microgrids, including those for remote communities and those in underserved areas, critical infrastructure, EV charging stations, commerce, industry, and military bases.

d INL identified 25 Functional Requirements for the Microgrid Modeling Platform that are needed for as a starting point to develop a NZC Microgrid Planning and Design Tool. These are divided into three major categories: 1) End-to-End Integration Microgrid Design and Implementation, 2) Collaboration and Ease of Use, and 3) Technical and Financial. Within these categories is the capability to model GHG emissions (see Annex B, "Microgrid Modeling Platform"). To select the most-qualified software package, INL evaluated eight software packages from national laboratories and commercial vendors, against these requirements. XENDEE was the only source with a comprehensive platform that met all 25 requirements (the other vendors offered from 7 to 12 of the 25; none for GHG.) 
The NZM Design Platform will be distinguished by its capability to optimize microgrids - generation using fossil and renewable energy, carbon-free generation, storage and flexible loads - with reduced GHG emissions as an objective. The NZM will deliver a modeling tool that optimizes renewables and minimizes GHG emissions, along with the most-advanced capabilities for technical and economic planning and design available on the market today.

The NZM will bring these capabilities into INL, fully integrated, with the extra value of GHG as a metric for microgrids. See Annex B for on the functional requirements of the Microgrid Modeling Platform.

\subsubsection{Approach}

A well-considered approach to rapidly decarbonizing microgrids is required. As this report shows, over $75 \%$ of generation in microgrids is fueled by diesel or natural gas, which creates serious negative consequences for climate change and resiliency. As microgrids are driven toward carbon-free technologies that both support resilience and advance adoption of renewable-energy technologies, NZMs will become a synergistic partner within the context of an emerging carbon-free economy. This section addresses many of the pieces of a strategy to make microgrids carbonless and grow their use beyond localized resiliency toward introducing more well-organized and controlled aggregations of renewable and zero-carbon generation to the power system. Thus, the approach of the NZM Program places microgrids as the cornerstone of green resilience and green communities.

Practically speaking, we can only assess improvement by comparing an existing condition with the outcomes of change. With respect to NZM, the approach is to measure outcomes in terms of the value of carbon reduction. The major innovation required to do so is the creation of an analytical tool which measures emissions as part of optimization in the planning and design for new and upgraded microgrids. The proposed tool would improve on existing design models by including GHG calculations in such a way that designers and policymakers can consider the tariffs and incentives necessary to drive the reductions needed. The tool will also facilitate substitution of renewable generation, storage, and control over flexible loads for fossil-fuel-burning generation in a way that maintains dispatchability and stability of microgrids in both grid-connected and islanded operational modes.

The NZM Program approaches these challenges by addressing the technical issues, developing the tools, and performing the analysis and studies for transition to net-zero microgrids as a practical reality in the industry. The near-term goal for NZM is microgrids with GHG emissions reduced by $<50 \%$, compared to 2020 , demonstrated and validated in the field.

\subsection{Research and Development}

Among the research and development projects that are identified as flowing from the NZM Program, enabled by the tools developed, are

1. Modeling of new types of generators and new fuels and fuel mixes in generators for performancee.g., response to signals, ramping, in NZC microgrids

2. NZC microgrid configurations with high content renewable generation, modeling for different applications - e.g., critical infrastructure, military bases, communities, EV charging stations

3. Advanced planning tools that can handle more-complex owner structures, grid-topologies, power flows, local energy markets, different tariff systems, dynamic pricing, and smaller time-steps to capture the volatility of renewables and tools that can handle optimization and planning in small steps (e.g., 5 mins) effectively

4. New controller techniques for handling/managing microgrids and aggregations of DER with $80 \%$ generation from renewable energy 
5. Metrics for microgrid operations considering time dimension for ratings for renewable energy generation assets in microgrids

6. Resiliency evaluation of NZC microgrids metrics and calculator

7. GHG Emissions Calculator-Microgrids

8. NZC models for microgrid applications: generic for disadvantaged areas

9. NZC microgrid modeling tools, availability to the public

10. Microreactor module for NZC microgrid modeling, highlighting zero emissions (ongoing for $\mathrm{SMR} /$ microreactors)

11. NZC microgrid implementation toolkits by application

12. Tax-incentive emission reduction (TIER) plan for NZC microgrids. 


\section{DEFINITIONS}

Dispatchable generation, resource, power supplies. Generation or sources of electricity that can be dispatched on demand at the request of power grid operators, to meet load and demand. Dispatchable generators can adjust their power output according to an order. They include coal and natural gas power plants, nuclear power plants, and hydroelectric power plants using water reservoirs.

Non-dispatchable generation. Generation based on renewable energy sources such as wind turbines and SPVs, where power cannot be controlled by operators. Intermittent wind and SPV power generation variability and intermittency can be balanced using electric energy storage systems.

Energy storage systems. Systems that capture energy produced at one time for use at a later time. Can be used to reduce imbalances between energy demand and energy production. The more-common storage systems are based on electrochemical batteries.

Inverter-based system. System that converts power from direct current (dc) to alternating current (ac), the dc power being supplied from a wind turbine or a solar PV installation, or a battery, and the ac side being connected to the ac electric grid. The system is the interface between the primary dc power source, wind, solar, battery, and the grid and allows power transfer with the grid.

Net-zero carbon. A commitment to reducing greenhouse gas emissions with the goal of balancing the emissions produced and emissions removed from the earth's atmosphere. ${ }^{13}$

Net-zero. A target of completely negating the amount of greenhouse gases produced by human activity, to be achieved by reducing emissions and implementing methods of absorbing carbon dioxide from the atmosphere. Net-zero refers to the balance between the amount of greenhouse gas produced and the amount removed from the atmosphere. We reach net zero when the amount we add is no more than the amount taken away. 


\section{REFERENCES}

8.1 Works Cited

[1] US microgrid forecast: H2 2021, October 21, 2021, Wood-Mackenzie.

[2] EIA. 2020. Sources of U.S. Electricity Generation.

https://www.eia.gov/energyexplained/electricity/electricity-in-the-us-generation-capacity-andsales.php\#: : :text $=$ In $\% 202020 \% 2 \mathrm{C} \% 20$ about $\% 2060 \% 25 \% 20$ of,was $\% 20$ from $\% 20$ renewable $\% 20$ ener gy\%20sources

[3] Tim Hansen. 2020. "Only proper microgrid design will ensure maximum carbon reduction in energy systems," Power Grid International. January 8, 2020. https://www.power-grid.com/der-gridedge/only-proper-microgrid-design-will-ensure-maximum-carbon-reduction-in-energy-systems/\#gref.

[4] Alex Metz et al. 2020. Integrated DER: Orchestrating the Grid's Last Mile, Guidehouse, 3Q 2020. https:/guidehouse.com/-/media/www/site/insights/energy/2020/gh_integrated-der_2020.pdf.

[5] Andrew Foss et al. 2021. "NRIC Integrated Energy Systems Demonstration Pre-Conceptual Designs: Report for Project RC-21IN020701." INL EXT-21-61413, Idaho National Laboratory. https://nric.inl.gov/wp-content/uploads/2021/06/NRIC-IES-Demonstration-Pre-conceptual-DesignsReport-1.pdf.

[6] U.S. House of Representatives. 2021. H.R. 2482, "Microgrid Act," 117th Congress.

[7] CPUC. 2021. Decision Adopting Rates, Tariffs, and Rules Facilitating the Commercialization of Microgrids Pursuant to Senate Bill 1339 and Resiliency Strategies. Agenda ID 19048, Rev.1. https://docs.cpuc.ca.gov/PublishedDocs/Published/G000/M359/K865/359865952.PDF

[8] Hawaii Electric. 2021. "Hawai'i microgrid tariff seen as model for other states." News Release, https://www.hawaiianelectric.com/documents/about us/news/2021/20210628 microgrid services tariff.pdf.

[9] Steven Nadel, James Gaede, and Brendon Haley. 2021. "State and Provincial Efforts to Put a price on Greenhouse Gas Emissions.” American Council for an Energy-Efficient Economy. March 2, 2021.

[10] Kathleen Spees. 2020. “The Integrated Clean Capacity Market, A Design Option for New England's Grid Transition," Presentation to the New England Power Pool, Brattle, October 1, 2020.

https://www.brattle.com/insights-events/publications/the-integrated-clean-capacity-market-a-designoption-for-new-englands-grid-transition/.

[11] Jeff St. John. 2021. "Location matters: The new science of siting clean energy to push more carbon from the grid," Canary Media. 20 September 2021. https://www.canarymedia.com/articles/cleanenergy/location-matters-the-new-science-of-targeting-clean-energy-to-push-more-carbon-from-thegrid.

[12] David Luke Oates and Kathleen Spees, 2021. "Locational Marginal Emissions: A Force Multiplier for the Carbon Impact of Clean Energy Programs," ReSurety. https://resurety.com/wpcontent/uploads/2021/05/REsurety-Locational-Marginal-Emissions-A-Force-Multiplier-for-theCarbon-Impact-of-Clean-Energy-Programs.pdf.

[13] Herbert Smith Freehills, "Carbon neutral vs net-zero: What's the difference? (and why does it matter) https://www.herbertsmithfreehills.com/carbon-neutral-and-net-zero-carbon-whats-thedifference-and-why-does-it-matter 


\subsection{Bibliography}

Select Bibliography, taken from an extensive literature search on net-zero energy solutions and microgrids.

- G. Holdmann, G. Roe, S. Colt, H. Mekel, and K. Mayo. "Small Scale Nuclear Power: An Option for Alaska?" Alaska Center for Energy and Power. University of Alaska Fairbanks. Jan. 2021

- S. Waldman. "Biden's Infrastructure Plan Would Make Electricity Carbon-Free by 2035." Scientific America. E\&E News. Apr. 2021

- M. Archibong and E. McCormick. "FERC Issues Policy Statement on Carbon Pricing in Organized Wholesale Electric Markets." Energy Central News. May 2021

- $\quad$ N. Abhyankar, U. Paliwal, T. McNair, D. Wooley, M. O’Boyle, and A. Phadke. "2030 Report: Powering America's Clean Economy." Goldmans school of Public Policy. University of California Berkeley. Apr. 2021

- San Diego Gas \& Electric Company. "Building a Better Future: Paving the way to a Net Zero Future." 2021

- $\quad$ M. Stadler, Z. Pecenak, P. Mathiesen, K. Fahy, and J. Kleissl. "Performance Comparison Between Two Established Microgrid Planning MILP Methodologies Tested On 13 Microgrid Projects.” MDPI Energies. Aug. 2020

- Decision Requiring Procurement to Address Mid-term Reliability (2023-2026). Proposed Decision (Rev. 1). Agenda ID \#19549. Jun. 2021

- Decision Adopting Rates, Tariffs, and Rules Facilitating the Commercialization of Microgrids Pursuant to Senate Bill 1229 and Resiliency Strategies. Proposed Decision (Rev. 1). Agenda ID \#19048. Jan. 2021

- "United States Distributed Energy Resources Outlook: Executive Summary Snapshot." Wood Mackenzie Power \& Renewables. Jul. 2020.

- "Diesel Back-Up Generator Population Grows Rapidly in the Bay Area and Southern California." M. Cubed. Policy Analysis for the Public and Private Sectors. 2020

- "Distributed Generation of Electricity and its Environmental Impacts." United States Environmental Protection Agency (EPA). Energy and the Environment.

https://www.epa.gov/energy/distributed-generation-electricity-and-its-environmental-impacts

- P. Harrop, Z. He, and D. Gatti. "Distributed Generation: Off-Grid Zero-Emission kW-MW 20202040." https://www.idtechex.com/en/research-report/distributed-generation-off-grid-zeroemission-kw-mw-2020-2040/730

- "Electricity Generation, Capacity, and Sales in the United States." U.S. Energy Information Administration. https://www.eia.gov/energyexplained/electricity/electricity-in-the-us-generationcapacity-and-sales.php

- B. Magavern. "Eliminate California's Reliance on Diesel Backup Generators." CalMatters. Apr. 5, 2021.

- R. Wallsgrove, J. Woo, J. Lee, and L. Akiba. "The Emerging Potential of Microgrids in the Transition to 100\% Renewable Energy Systems.” MDPI Energies. 2021. 
- E. Wesoff. "Biden Going Nuclear with a Tax Credit? Plus, an Advanced Reactor News Roundup.” May 2021.

- $\quad$ R. Hanna, M. Ghonima, J. Kleissl, G. Tynan, and D. Victor. "Evaluating Business Models for Microgrids: Interactions of Technology and Policy.” Elsevier. Energy Policy. 2017

- "The Next Five Years Will See Massive Distributed Energy Resource Growth. Wood Mackenzie. Jun. 2020. Mackenziehttps://www.woodmac.com/news/editorial/der-growth-united-states/

- S. Moss and A. Bilich. "Hidden Grid: More Than Eight Gigawatts of Fossil Fueled Back-Up Generators Located in Just Five California Districts.” M.Cubed Policy Analysis for the Public and Private Sectors. May 2020

- "How Clean is Natural Gas? Greenhouse Gas Emissions by the Numbers." Clean Energy Compression. Feb. 19, 2016

- C. Lewis. "How the Resilient Energy Subscription Market Mechanism Will Help Finance Community Microgrids.” Utility Dive. Sep. 22, 2021

- "PG\&E Comments on Proposed Research for Hydrogen Blending." Docket Number 19-ERDD01. Docketed Date Apr. 9, 2021

- Z. Pecenak, P. Mathiesen, K. Fahy, C. Cannon, E. Ayandele, T.J. Kirk, and M. Stadler. "The Impact of Project Financing in Optimizing Microgrid Design." Journal of Renewable and Sustainable Energy. Nov. 2020

- “Japan-U.S. New Mexico Smart Grid Collaborative Demonstration Project." New Energy and Industrial Technology Development Organization (NEDO). Feb. 2015

- J. John. "Location Matters: The New Science of Siting Clean Energy to Push More Carbon From the Grid." Canary Media. Sep. 20, 2021. https://www.canarymedia.com/articles/cleanenergy/location-matters-the-new-science-of-targeting-clean-energy-to-push-more-carbon-fromthe-grid

- "Marginal Emissions Rate - A Primer." Pennsylvania, New Jersey, and Maryland (PJM)

- $\quad$ K. Sirvio, K. Kauhaniemi, A. Memon, H. Laaksonen, and L. Kumpulainen. "Functional Analysis of the Microgrid Concept Applied to Case Studies of the Sundom Smart Grid." MDPI Energies. Aug. 2020

- J. Spector. "Microgrid Expansion Could Lock in Carbon Emissions Without Policy Safeguards." Green Tech Media. https://www.greentechmedia.com/articles/read/microgrid-expansion-couldlock-in-carbon-emissions-without-policy-safeguard

- E. Wood. "21 Intriguing Microgrid Projects to Watch in 2021." Microgrid Knowledge. Jan. 5, 2021

- Califofrnia Public Utilities Commission. "Decision Adopting A Suspension of the Capacity Reservation Component of the Standby Charge for Eligible Microgrid Distributed Technologies." Proposed Decision, Agenda ID \#19602 (Rev. 1) Ruelemaking 19-09-009. Jun 9, 2021

- California Public Utilities Commission. "Decision Adopting Rates, Tariffs, and Rules Facilitating the Commercialization of Microgrids Pursuant to Senate Bill 1339 and Resiliency Strategies." Rulemaking 19-09-009. Jan. 21, 2021

- Microgrids. Center for Climate and Energy Solutions. https://www.c2es.org/content/microgrids/ 
- S. Marchand, C. Monsalve, T. Reimann, W. Heckmann, J. Ungerland, H. Lauer, S. Ruhe, and C. Krauß. "Microgrid Systems: Towards a Technical Performance Assessment Frame." MDPI Energies. 2021

- C. Lenton. "Natural Gas Generation Nabs Growing Share of Installed U.S. Microgrid Capacity." 2021 Natural Gas Intelligence

- "Smart, Clean Neighborhood Grids: Redesigning Our Electric System to Help Communities Power Through Blackouts." Sunrun

- "Net Zero by 2050: A Roadmap for the Global Energy Sector.” International Energy Agency (IEA). 2021

- J. Giraldez, F. Flores-Espino, S. MacAlpine, and P. Asmus. "Phase I Microgrid Cost Study: Data Collection and Analysis of Microgrid Cost in the United States." National Renewable Energy Laboratory (NREL). Tech. Report NREL/TP-5D00-67821 October 2018

- "NeI's New Ad Campaign "See the Light” Embraces a Carbon-Free Future." Nuclear Energy Institute. Aug. 4, 2021

- T. Hansen. "Only Proper Microgrid Design will Ensure Maximum Carbon Reduction in Energy Systems.” Power Grid International. Jan. 8, 2020

- M. Tahmasebi, J. Pasupuleti, F. Mohamadian, M. Shakeri, J. Guerrero, M. Khan, M. Nazir, A. Safari, and N. Bazmohammadi. "Optimal Operation of Stand-Alone Microgrid Considering Emission Issues and Demand Response Program Using Whale Optimization Algorithm.” MDPI Sustainability. 2021

- H. Trabish. "PG\&E, SCE Abandon Big Microgrid Plans for Temporary Emergency Measures as Wildfire Season Nears." Utility Dive. Mar. 23, 2020

- "Disposition Partially Approving Advice Letter Requesting to Reserve Temporary Generation for use at Substations in 2021." State of California. Public Utilities Commission. Advice Letter 6105E. Apr. 14. 2021

- "Record Number of Microgrids Installed in US Last Year." A Verisk Business Wood Mackenzie. Jul. 22, 2020

- D. Xu and Y. Long. "The Impact of Government Subsidy on Renewable Microgrid Investment Considering Double Externalities.” MDPI Sustainability. 2019

- C. Lewis. "Resilient Energy Subscription for Financing Community Microgrids." Clean Coalition. 2021 https://clean-coalition.org/news/resilient-energy-subscription-for-financingcommunity-microgrids/

- K. Varri and S. Syri. "The Possible Role of Modular Nuclear Reactors in District Heating: Case Helsinki Region.” MDPI Energies. 2019

- V. Gavan, A. Rostaing, A. Partaloglu, and C. Muresan. "Self-Sufficient Microgrid - Feasibility Study on Atlantech Low Carbon District." ECEEE Proceedings. 2019

- D. Esposito. "Studies Agree 80 Percent Clean Electricity by 2030 Would Save Lives and Create Jobs at Minimal Cost.” Energy Innovation Policy \& Technology. 2021

- "US Microgrid Forecast H1 2020 Coronavirus Delays Projects and Impacts Origination.” Wood Mackenzie Power \& Renewables. 2020 
- "Advancing the Growth of the U.S. Wind Industry: Federal Incentives, Funding, and Partnership Opportunities.” U.S. Department of Energy. Office of Energy Efficiency \& Renewable Energy. 2021

- E. Penrod. "Wind, Solar to Make Up 70\% of New US Generation Capacity in 2021 While Batteries Gain Momentum: EIA" Utility Dive. Jan. 13, 2021 


\section{Appendix A \\ Microgrid Installations-Generation Mix}


Page intentionally left blank 


\section{Appendix A \\ Microgrid Installations-Generation Mix (Examples)}

Table A-1. Microgrid installations, generation by fuel (kw) and storage.

\begin{tabular}{lcccc} 
SPIDERS (Joint Base Pearl Harbor-Hickam) & Generation + Storage & \multicolumn{2}{c}{ Generation only } \\
Fuel Type & KW & Ratio & KW & Ratio \\
Generators (diesel) & 2,400 & $62.3 \%$ & 2,400 & $92.3 \%$ \\
PV & 150 & $3.9 \%$ & 150 & $5.8 \%$ \\
Wind & 50 & $1.3 \%$ & 50 & $1.9 \%$ \\
Storage & 1,250 & $32.5 \%$ & 0 & $0.0 \%$ \\
Total & 3,850 & $100.0 \%$ & 2,600 & $100.0 \%$
\end{tabular}

\begin{tabular}{lcccc}
\multicolumn{1}{c}{ SPIDERS (Camp Smith) } & & & & \\
Fuel Type & KW & Ratio & KW & Ratio \\
Generators (diesel) & 5,000 & $89.3 \%$ & 5,000 & $94.3 \%$ \\
PV & 300 & $5.4 \%$ & 300 & $5.7 \%$ \\
Storage & 300 & $5.4 \%$ & 0 & $0.0 \%$ \\
Total & 5,600 & $100.0 \%$ & 5,300 & $100.0 \%$
\end{tabular}

\section{SPIDERS (Fort Carson)}

$\begin{array}{lcccc}\text { Fuel Type } & \text { KW } & \text { Ratio } & \text { KW } & \text { Ratio } \\ \text { Generators (diesel) } & 2,900 & 74.4 \% & 2,900 & 74.4 \% \\ \text { PV } & 1,000 & 25.6 \% & 1,000 & 25.6 \% \\ \text { Total } & 3,900 & 100.0 \% & 3,900 & 100.0 \%\end{array}$

\section{PEARL Microgrid (JBPH)}

$\begin{array}{lcccc}\text { Fuel Type } & \text { KW } & \text { Ratio } & \text { KW } & \text { Ratio } \\ \text { Generator (diesel) } & 1,000 & 27.5 \% & 1,000 & 38.0 \% \\ \text { PV - Microgrid } & 134 & 3.7 \% & 134 & 5.1 \% \\ \text { PV - Existing solar array outside microgrid } & 1,500 & 41.3 \% & 1,500 & 56.9 \% \\ \text { Storage } & 1,000 & 27.5 \% & 0 & 0.0 \% \\ \text { Total } & 3,634 & 100.0 \% & 2,634 & 100.0 \%\end{array}$




\section{MIRAMAR}

$\begin{array}{lcccc}\text { Fuel Type } & \text { KW } & \text { Ratio } & \text { KW } & \text { Ratio } \\ \text { Natural Gas Reciprocating Engines } & 2,800 & 21.6 \% & 2,800 & 25.6 \% \\ \text { Diesel Reciprocating Engines } & 3,650 & 28.2 \% & 3,650 & 33.3 \% \\ \text { Landfill gas } & 3,200 & 24.7 \% & 3,200 & 29.2 \% \\ \text { Solar } & 1,300 & 10.0 \% & 1,300 & 11.9 \% \\ \text { Storage (batteries) } & 2,000 & 15.4 \% & 0 & 0.0 \% \\ \text { Total } & 12,950 & 100.0 \% & 10,950 & 100.0 \%\end{array}$

\section{SANTA RITA JAIL}

$\begin{array}{lcccc}\text { Fuel Type } & \text { KW } & \text { Ratio } & \text { KW } & \text { Ratio } \\ \text { Generators (diesel) } & 2,400 & 30.8 \% & 2,400 & 41.4 \% \\ \text { Fuel cell power plant } & 1,000 & 12.8 \% & 1,000 & 17.2 \% \\ \text { PV (rooftop) } & 1,200 & 15.4 \% & 1,200 & 20.7 \% \\ \text { Wind turbines }(5 * 2.3 \mathrm{~kW}) & 1,200 & 15.4 \% & 1,200 & 20.7 \% \\ \text { Storage } & 2,000 & 25.6 \% & 0 & 0.0 \% \\ \text { Total } & 7,800 & 100.0 \% & 5,800 & 100.0 \%\end{array}$

\section{BLUE LAKE RANCHERIA}

\begin{tabular}{lcccc} 
Fuel Type & KW & Ratio & KW & Ratio \\
Diesel generator & 1,000 & $50.0 \%$ & 1,000 & $66.7 \%$ \\
Diesel generator (backup) & 80 & $4.0 \%$ & 80 & $5.3 \%$ \\
PV System & 420 & $21.0 \%$ & 420 & $28.0 \%$ \\
Storage & 500 & $25.0 \%$ & 0 & $0.0 \%$ \\
Total & 2,000 & $100.0 \%$ & 1,500 & $100.0 \%$ \\
\hline
\end{tabular}

\begin{tabular}{lcccc}
\multicolumn{1}{c}{ BRONZEVILLE (COMED) } & & & & \\
\hline Fuel Type & KW & Ratio & KW & Ratio \\
Generator (natural gas) & 5,500 & $81.5 \%$ & 5,500 & $88.0 \%$ \\
PV & 750 & $11.1 \%$ & 750 & $12.0 \%$ \\
Storage & 500 & $7.4 \%$ & 0 & $0.0 \%$ \\
Total & 6,750 & $100.0 \%$ & 6,250 & $100.0 \%$ \\
\hline
\end{tabular}

\begin{tabular}{lcccc}
\multicolumn{1}{c}{ NAVY YARD } & & & & \\
Fuel Type & $\mathrm{KW}$ & Ratio & $\mathrm{KW}$ & Ratio \\
Generator (natural gas) & 8,000 & $52.6 \%$ & 8,000 & $88.9 \%$ \\
Fuel Cell & 600 & $3.9 \%$ & 600 & $6.7 \%$ \\
Solar (rooftop) & 400 & $2.6 \%$ & 400 & $4.4 \%$ \\
Storage & 6,200 & $40.8 \%$ & 0 & $0.0 \%$ \\
Total & 15,200 & $100.0 \%$ & 9,000 & $100.0 \%$
\end{tabular}




\begin{tabular}{lcccc}
\multicolumn{1}{c}{ UC IRVINE } & & & & \\
Fuel Type & $\mathrm{KW}$ & Ratio & $\mathrm{KW}$ & Ratio \\
Generator (gas turbine) & 13,500 & $52.7 \%$ & 13,500 & $57.2 \%$ \\
Generator (steam turbine) & 6,000 & $23.4 \%$ & 6,000 & $25.4 \%$ \\
PV & 4,113 & $16.1 \%$ & 4,113 & $17.4 \%$ \\
Storage & 2,000 & $7.8 \%$ & 0 & \\
Total & 25,613 & $100.0 \%$ & 23,613 & $100.0 \%$
\end{tabular}

\begin{tabular}{lcccc}
\multicolumn{1}{c}{ Ft Custer (ESTCP 2020) } & & & & \\
Fuel Type & KW & Ratio & KW & Ratio \\
800kW, 480VAC Caterpillar diesel generator & 800 & $35.2 \%$ & 800 & $35.2 \%$ \\
750kW, 480VAC Cummins diesel generator & 750 & $33.0 \%$ & 750 & $33.0 \%$ \\
720kW solar array with PV inverters & 720 & $31.7 \%$ & 720 & $31.7 \%$ \\
Total & 2270 & $100.0 \%$ & 2,270 & $100.0 \%$
\end{tabular}


Page intentionally left blank 


\section{Appendix B Microgrid Modeling Platform}


Page intentionally left blank 


\section{Appendix B Microgrid Modeling Platform}

Table B-1. Functions and requirements.

\begin{tabular}{|c|c|c|}
\hline & Function & Requirements \\
\hline \multirow{7}{*}{ 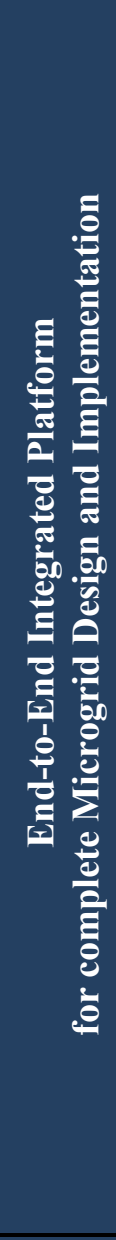 } & Project Screening & $\begin{array}{l}\text { Archive of technologies, utility data, fuel costs, etc.) to } \\
\text { enable fast screening of projects }\end{array}$ \\
\hline & GIS, integrated & $\begin{array}{l}\text { GIS based design level to enable grid topology and on-site } \\
\text { detailed power flow analysis, integrated with the platform. }\end{array}$ \\
\hline & $\begin{array}{l}\text { Detailed Economic } \\
\text { Engineering }\end{array}$ & $\begin{array}{l}\text { Key features include fast multi-year analyses in minutes } \\
\text { that allow investment time-lines depending on changing } \\
\text { constraints (e.g., tariffs, storage performance degradation) } \\
\text { over time; detailed efficiency curves Consideration of } \\
\text { microgrid controller functions Capability to perform } \\
\text { power flow across multiple nodes (e.g., buses, loads, } \\
\text { generation locations) during the economic design phase } \\
\text { (to consider bottlenecks in the distribution system early in } \\
\text { the design phase). }\end{array}$ \\
\hline & $\begin{array}{l}\text { Carbon emission reduction as } \\
\text { an objective function }\end{array}$ & $\begin{array}{l}\text { Provide } \mathrm{CO}_{2} \text {-minimization strategies as an objective. } \\
\text { Carbon emissions are modeled as a as important as costs } \\
\text { and resiliency. }\end{array}$ \\
\hline & $\begin{array}{l}\text { Distributions System } \\
\text { Modeling (Power flow) }\end{array}$ & $\begin{array}{l}\text { Full time-series power flow analyses in any time } \\
\text { resolution and for as many nodes as the project requires. } \\
\text { Identify voltage or line problems in the microgrid or DER } \\
\text { project area. } \\
\text { This function must be integrated in the platform. }\end{array}$ \\
\hline & $\begin{array}{l}\text { Transient Stability } \\
\text { Modeling }\end{array}$ & $\begin{array}{l}\text { Analytics for dynamics in the system for black start } \\
\text { capabilities. }\end{array}$ \\
\hline & Project Management Tools & $\begin{array}{l}\text { Provide time-lines, issue tracking, project summaries, as } \\
\text { well as on-the-job online training to efficiently perform } \\
\text { the microgrid and DER project implementation. }\end{array}$ \\
\hline \multirow{4}{*}{ 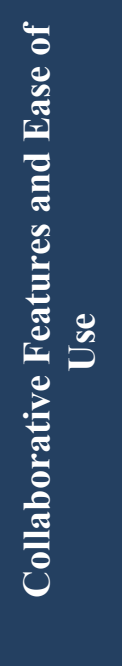 } & $\begin{array}{l}\text { Share project status and results } \\
\text { among users via platform }\end{array}$ & $\begin{array}{l}\text { Ability for every team member to share projects within } \\
\text { his/her team directly on the platform. }\end{array}$ \\
\hline & $\begin{array}{l}\text { Share custom data catalogs } \\
\text { among users via platform }\end{array}$ & $\begin{array}{l}\text { Ability to share technology catalogs, data collected during } \\
\text { project development phases. }\end{array}$ \\
\hline & Single integrated workflow & $\begin{array}{l}\text { Allow transfer of same model through all design phases } \\
\text { on platform. } \\
\text { Connect economic and electrical engineering features } \\
\text { Allow through the entire design and engineering process } \\
\text { without the need for data conversions or using a different } \\
\text { platform. }\end{array}$ \\
\hline & One-line diagram interface & $\begin{array}{l}\text { One-line diagram of distribution system (detail for power } \\
\text { flow analysis between grid and microgrid). } \\
\text { Distribution system topologies clearly shown. } \\
\text { Graphical interface for designs within the network. }\end{array}$ \\
\hline
\end{tabular}




\begin{tabular}{|c|c|c|}
\hline & $\begin{array}{l}\text { Built-in major catalog } \\
\text { categories }\end{array}$ & $\begin{array}{l}\text { Major catalog categories: DER performance } \\
\text { characteristics and costs, utility tariffs, circuit element } \\
\text { parameters (for transformers and cables, among others), } \\
\text { load shapes }\end{array}$ \\
\hline \multirow{10}{*}{ 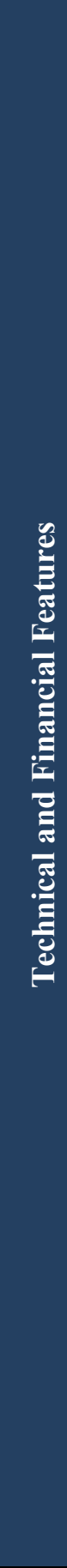 } & $\begin{array}{l}\text { Maintenance of online versions } \\
\text { of software }\end{array}$ & $\begin{array}{l}\text { Integrated platform that offers all its extended features via } \\
\text { cyber-secure web platform that allows for fast and unified } \\
\text { updates across all users without burdensome re- } \\
\text { installations of software updates. }\end{array}$ \\
\hline & $\begin{array}{l}\text { Modeling multiple financing } \\
\text { schemes }\end{array}$ & $\begin{array}{l}\text { Allow modeling of multiple financing strategies, e.g., } \\
\text { equipment leasing, market participation rights, loans, } \\
\text { equity, PPA). }\end{array}$ \\
\hline & $\begin{array}{l}\text { Derivative-based economic } \\
\text { optimization algorithms }\end{array}$ & $\begin{array}{l}\text { Derivative-based optimization algorithms that co-optimize } \\
\text { DER technologies/capacities as well as operation of the } \\
\text { microgrid. }\end{array}$ \\
\hline & $\begin{array}{l}\text { Multi-year planning for } \\
\text { enhanced financial indicators } \\
\text { (e.g., IRR, ROI, NPV) }\end{array}$ & $\begin{array}{l}\text { Adaptive multi-year analysis capabilities to solve within } \\
\text { minutes compared to hours or days and reassess for each } \\
\text { year the optimal investment and operational strategies, } \\
\text { given the results from prior years. Identify optimal DER } \\
\text { selection and capacity, as installation year is influenced by } \\
\text { projected changes (e.g., costs, site demand). }\end{array}$ \\
\hline & $\begin{array}{l}\text { Multi-objective economic and } \\
\text { emissions optimization }\end{array}$ & $\begin{array}{l}\text { Allows the creation of frontier points that show costs to } \\
\text { reduce carbon emissions to a certain level. }\end{array}$ \\
\hline & $\begin{array}{l}\text { Utility grid outage as well as } \\
\text { DER technologies redundancy } \\
\text { modeling }\end{array}$ & $\begin{array}{l}\text { Outage modeling approach that guarantees energy supply } \\
\text { at every time-step and also considers DER technology } \\
\text { failures (e.g., generators). Optimize system operation } \\
\text { through modeled outages to identify the portion of critical } \\
\text { and non-critical loads that is optimal to meet or curtail at } \\
\text { any given hour, taking into account user-set costs of } \\
\text { unserved load. }\end{array}$ \\
\hline & $\begin{array}{l}\text { Power flow and distribution } \\
\text { aspects in economic design } \\
\text { phase }\end{array}$ & $\begin{array}{l}\text { In the economic design phase consider multiple nodes } \\
\text { (e.g., buses, loads, generation locations) and the } \\
\text { distribution network. }\end{array}$ \\
\hline & $\begin{array}{l}\text { Automated reporting } \\
\text { throughout design process }\end{array}$ & $\begin{array}{l}\text { Integrated platform that bundles all steps of the DER } \\
\text { and/or Microgrid design process; automated reporting for } \\
\text { main design steps for project screening, feasibility studies, } \\
\text { as well as distribution system modeling. }\end{array}$ \\
\hline & $\begin{array}{l}\text { Auto-sizing of electrical } \\
\text { infrastructure }\end{array}$ & $\begin{array}{l}\text { Cable line length calculations (GIS-based); auto sizing of } \\
\text { cables for greenfield projects based on optimal DER } \\
\text { capacities. }\end{array}$ \\
\hline & Energy domains modeled & $\begin{array}{l}\text { Cooling, refrigeration, heating, domestic hot water, } \\
\text { hydrogen, and natural gas loads to allow energy carrier } \\
\text { switching (e.g., solar thermal cooling) }\end{array}$ \\
\hline
\end{tabular}




\begin{tabular}{|c|c|}
\hline $\begin{array}{l}\text { DER and Microgrid } \\
\text { Technologies modeled }\end{array}$ & $\begin{array}{l}\text { DER:| } \\
\text { PV, electric storage, flow batteries, wind turbines, fuel- } \\
\text { fired generators, CHP, inverters, boilers, central heating, } \\
\text { ventilation, and air conditioning, heat pumps, absorption } \\
\text { chillers, thermal storage and cold water storage, solar } \\
\text { thermal, electric vehicles, hydroelectric, biomass, and } \\
\text { hydrogen fuel cells. } \\
\text { Microgrid controller functions (IEEE 2030.7) } \\
\text { Power System: cables, transformers, and buses. }\end{array}$ \\
\hline Value streams & $\begin{array}{l}\text { Behind-the-meter self-generation, load shifting, load } \\
\text { shedding, peak shaving, electricity sales, demand } \\
\text { response, ancillary services, resilience, load curtailment, } \\
\text { tax incentives. }\end{array}$ \\
\hline $\begin{array}{l}\text { Analytical capabilities for } \\
\text { power distribution modeling }\end{array}$ & $\begin{array}{l}\text { Criteria: } \\
\text { Power/load-flow time-series analysis, islanded operation, } \\
\text { motor starting, arc flash, fault analysis, harmonics, simple } \\
\text { dynamics, short-circuit analysis, distribution automation, } \\
\text { volt/VAR optimization, device coordination, feeder } \\
\text { reconfiguration, fault detection and restoration, transient } \\
\text { stability analysis. }\end{array}$ \\
\hline Technical and financial outputs & $\begin{array}{l}\text { Major outputs: } \\
\text { Optimal solution for DER selection/sizing, DER } \\
\text { placement, system operation, incentive programs } \\
\text { Resilience strategy, load management strategy, annual } \\
\text { costs and emissions, upfront and annualized investment } \\
\text { costs, projected year-by-year NPV/IRR/ROI. } \\
\text { Detailed cash flow, network voltages and losses; voltage } \\
\text { and active/reactive power flow, Timeline for DER } \\
\text { investment and system operation, short circuit currents, } \\
\text { line and cable loading, transient analysis results. }\end{array}$ \\
\hline
\end{tabular}


Page intentionally left blank 


\section{Appendix C Revenue from Markets-New Concepts}


Page intentionally left blank 


\section{Appendix C \\ Revenue from Markets-New Concepts}

New concepts proposed for recognizing the value of carbon reduction for markets are capsulized below.

\section{C-1. INTEGRATED CLEAN CAPACITY MARKET ${ }^{10}$}

The concept of an integrated clean-capacity market is a package for an optimal resource mix that achieves objectives for resource adequacy for reliability and policy goals for clean energy. It co-optimizes the procurement of capacity and clean energy.

For example, the design concept for a three-year forward market would maintain key elements from today's market, while being a fit-for-purpose market for achieving an 80-100\% clean-electricity future. The concept would rely on states and customers establishing demand for unbundled "clean-energyattribute credits" which would subsidize bids into the market for a clean-energy resource, thus making them competitive.

\section{C-1.1 Emissionality Offsets ${ }^{11}$}

Carbon offsets that are directly related to projects connected to the power grid project are proposed to replace carbon emissions over their lifetime. Measuring and valuing emissionality is critical in capturing the benefits that need to be accounted for in structuring financing. Emissionality is defined as a measurement that relies on data to assess the impact of so-called "marginal emissions" - i.e., the contributions of clean-energy displacements. The data typically use average annual emission reductions as measured by the offset credits exchanged between clean-energy developers and buyers. Data on the carbon-reduction value of clean power projects in different locations are slowly emerging.

Location-i.e., a site's relationship to the transmission grid - is a key factor. If a new renewable project is built in an area with transmission bottlenecks, then some of the power it produces might not be consumed, and its value in reducing carbon emissions is lessened.

A tool from REsurety ${ }^{\mathrm{e}}$ offers a way to measure emissionality, which it refers to as "locational marginal emissions." This tool crunches data collected by federal agencies, system operators, and transmission organizations that manage transmission grids and energy markets for about two-thirds of U.S. electricity customers. These historical-emissions data are tied to the electricity consumption or generation at each node in the grid. This can be used to attach a carbon attribute to the renewable-energy credit to account for the emissions-intensity of replaced energy on an hourly basis, rather than the annual accounting now applied to these credits. Thus, the potential exists for emissions data to be bundled into the locational marginal price data for market participation.

\section{C-2. LOCATIONAL MARGINAL EMISSIONS ${ }^{12}$}

The direct clean-energy deployment of renewable projects at the locations with their highest-value has the potential to double the carbon impact. Setting goals and measuring performance using carbonbased metrics for projects can help select generation technologies, make siting decisions, and operate resources to minimize the carbon footprint.

Hannon Armstrong. An energy analytics company providing customers including Microsoft, Quinbrook Infrastructure Partners 


\section{C-2.1 What are Locational Marginal Emissions?}

Locational marginal emission (LME) is a measure of the tons of carbon emissions displaced by $1 \mathrm{MWh}$ of clean energy injected into the grid in a specific location at a specific point in time. LMEs are calculated at each power-system node in a manner very similar to the locational marginal price used to set wholesale electricity-market prices. LMEs measure emissions by identifying the marginal generators: the generators that would have been producing energy, but for the renewable injection to the grid at that location at that moment. If the renewable resource can displace output from a coal plant, the LME would reflect a high carbon impact of the clean-energy injection, but if the renewable resource is injecting power into an oversaturated region where renewables are already generating power, the LME would show a lowor zero-carbon impact from the clean-energy injection.

\section{C-2.2 LMEs Can Amplify the Impact of Clean Energy Programs}

Relative to the status quo, LMEs enable:

- Better generation technology selection

- Better siting decisions

- Accurate assessment of the carbon value of energy storage

- Better clean-energy procurements

- Alignment of interest between investors and power system operators

- Higher overall carbon abatement per dollar

- More-accurate accounting of the carbon footprint for companies that have committed to reductions.

\section{C-2.3 Marginal Emissions Rates ${ }^{f}$}

The marginal emissions rate for a given location is calculated by multiplying the average emissions rate for the individual marginal unit by the corresponding percentage for that unit. These rates are then added together to create the marginal emissions rate for the given location.

Emissions rates used in the calculations are average annual emissions rates (lb/MWh) for each generator. They do not reflect specific rates based on the exact output level of the generator at any given moment. For example, differing emissions rates might apply when a generator is first starting up, compared to when it is at maximum output, and these are not reflected. Pennsylvania-New JerseyMaryland (PJM) uses annual average rates based on public data sources. While there may be some inaccuracy as a result, PJM does not have access to more-detailed data.

f Marginal Emissions Rate - A Primer, PJM 